\title{
NÁZORY ČESKÝCH RODIČŮ A VEŘEJNOSTI NA ČASNÉ ROZDĚLOVÁNÍ ŽÁKU 1
}

\author{
DAVID GREGER, MARTIN CHVÁL, ELIŠKA WALTEROVÁ, KAREL ČERNÝ
}

Anotace: Český vzdělávací systém hojně využivá rozdělování žáků podle schopností do různých proudů vzdělávání. Zahraniční, ale také některé domácí, výzkumy pritom poukazují na nevýhody a rizika této praxe a doporučují nerozdělovat žáky na více a méně chytré $v$ průběhu povinné školní docházky. Nicméně limitujícím faktorem změn jsou často postoje veřejnosti a požadavky rodičù. $V$ této studii proto analyzujeme postoje rodičů $k$ různým typům rozdělování žáků a z baterie devíti otázek $k$ rozdělování žáků konstruujeme index inkluze, abychom odpověděli na otázku, jaké postoje má česká veřejnost k rozdělování. Pro vykreslení jednotlivých postojů využíváme také data z dalších výzkumů veřejného míněni provedených v posledních letech. $V$ závěru príspěvku si pak odpovídáme na otázku, zda jsou postoje veřejnosti v této oblasti natolik vyhraněné, že by nebylo možno je změnit, a na základě vhledu do dat se zamýšlíme nad tím, jak by bylo prípadně možno postoje veřejnosti k tomuto tématu dále ovlivnit.

Klíčová slova: výzkum veřejného mínění, vnější diferenciace, inkluzívní vzdělávání, postoje veřejnosti a rodičů, mimořádně nadaní, víceletá gymnázia.

\begin{abstract}
Czech educational system is characterized by early tracking of students into different types of schools based on their ability. Research evidence on the effects of tracking comes mainly from the US and UK. It stresses the impact of tracking on inequalities and also shows that tracking does not increase overall educational achievement. The criticism of tracking practices in the Czech Republic based on these findings however was in contrast with the public opinion, mainly with the attitudes of parents and general public. This paper thus study the attitudes of Czech parents and general public towards various types of differentiation in Czech educational system and we look for their attitudes to inclusion generally (we have built a scale on inclusion). The findings are based on the representative public opinion poll realized by the authors of this paper and uses also findings from other recent studies on attitudes toward schooling. Parents and public attitudes to inclusion are analyzed and authors also tries to answer whether these attitudes are stable or open to change.
\end{abstract}

Key words: public opinion poll, tracking, ability grouping, inclusive education, parents' and general public attitudes, gifted students, multi-year gymnasia.

1 Tento text vznikl v rámci řešení projektu Centra základního výzkumu školního vzdělávání (LC06046) podpořeného Ministerstvem školství, mládeže a tělovýchova ČR.

Autoři chtějí poděkovat kolegům, kteří svými podněty a kritickými připomínkami inspirovali autory při príípravě tohoto textu. Poděkování patří především Dominiku Dvořákovi, Janě Strakové a Arnoštovi Veselému. $V$ neposlední řadě chtějí autoři poděkovat dvěma anonymním recenzentům 


\section{1 ÚVODEM}

V tomto textu analyzujeme postoje rodičů a české veřejnosti k rozdělování žáků podle jejich schopností. Vzhledem k tomu, že český vzdělávací systém využívá nejrůznějších forem tohoto rozdělování žáků (např. základní školy s rozšířenou výukou jazyků či jiných předmětů, víceletá gymnázia), jedná se o otázku zásadní důležitosti. Zvláště proto, že současné poznání pedagogických, psychologických i sociologických výzkumů časné rozdělování žáků nedoporučuje. Ve vývoji českého školství po roce 1989 můžeme spatřovat nárůst uživání různých forem rozdělování žáků do výběrových škol a tříd, jehož nejtypičtějším příkladem bylo znovuzavedení víceletých gymnázií, a to v reakci na kritiku jednotné školy, která se stala pro mnohé prežitkem a symbolem socialistického rovnostářství vedoucího $\mathrm{k}$ nivelizaci úrovně vzdělanosti. Můžeme tedy říci, že otevření víceletých gymnázií bylo odpovědí na artikulované požadavky veřejnosti v rané fázi společenské transformace. S odstupem několika let začala být víceletá gymnázia kritizována s poukazy na zjištění pedagogických výzkumů a v roce 2001 pak v souladu s doporučeními Národního programu rozvoje vzdělávání v ČR (Bílá kniha) sociálně-demokratický ministr školství Eduard Zeman připravil návrh na opětovné zrušení víceletých gymnázií. Tento návrh však vyvolal bouřlivou mediální reakci a odmítnutí návrhu². Mediálně prezentované názory veřejnosti (resp. názory některých zainteresovaných skupin veřejnosti), které zabránily navrhovaným a připravovaným změnám, byly mnohými vnímáno jako obecně sdílený názor celé české veřejnosti, aniž by skutečné názory veřejnosti $k$ těmto otázkám byly nějak systematicky zjištovány.

Od konce 90. let se pak zvýšil zájem o problematiku víceletých gymnázií a kromě zkoumání dopadů rozdělování žáků se začala problematika víceletých gymnázií objevovat také ve výzkumech veřejného mínění (např. CVVM 2003, MEDIAN 2008, STEM/MARK 2009)3 ${ }^{3}$, přestože dřívější výzkumy se roli víceletých gymnázií a postojů $k$ nim vůbec nevěnovaly (AMD 1995 a 1999). V současné době pak z úst mnoha politiků slýcháme, že jsou si sice vědomi všech nevýhod, které rozdělování žáků přináší, ale co mají dělat, když to lidé tak chtějí. Ukazuje se tedy, že veřejné mínění prímo i neprímo ovlivňuje tvorbu vzdělávací politiky, a to platí zvláště ve vztahu ke struktuře systému a různým formám rozdělování žáků na základě jejich schopností. Hlubší porozumění postojům veřejnosti k otázkám časného rozdělování žáků tak nejen přináší informaci o smyšlení lidí, ale především umožňuje formulovat případné efektivní strategie, jak s těmito "názory“ pracovat. Domníváme se, že tento text zaplňuje mezeru v poznání názorů veřejnosti a rodičovské veřejnosti ve vztahu k rozdělování žáků a jeho různým formám.

za kritické připomínky, jejichž zapracování přispělo ke kvalitě textu.

Případnou korespondenci k textu posílejte k rukám D. Gregera na e-mail: david.greger@pedf.cuni.cz

2 Jsme si vědomi, že mnohdy argumenty pro zrušení gymnázií i argumenty jejich obhájců v podstatě v mnohém opakovaly diskuse, které se u nás vedly již v letech 1920 až 1948, tedy před zavedením jednotné školy a při hledání podoby vnitřně diferencované školy pro všechny (např. V. Př́hoda). O paralelách těchto diskusí jsme pojednali v jiném textu (viz Greger 2005).

3 Přehled výzkumů veřejného mínění k otázkám školství a vzdělávání podali Černý a Walterová (2006), tam Ize dohledat bližší údaje o odkazovaných výzkumech. 


\section{VÝZKUMY EFEKTŮ ČASNÉHO ROZDĚLOVÁNÍ ŽÁKŮ PODLE SCHOPNOSTÍ}

Výzkumy zjištujující dopady rozdělování žáků na základě jejich schopností do různých proudů studia mají dlouhou tradici především v anglosaském prostředí. První zásadní výzkumy, které přispěly ke kritice časté praxe rozdělování žáků do různých proudů vzdělávání, byly výzkumy založené na etnografických př́stupech. Za průlomové jsou považovány především práce etnografického výzkumu, který se zaměřoval na př́stup učitelů $k$ žákům ve výběrových a nevýběrových drahách a na redukci kurikula, stejně tak jako na chování žáků a školní klima v těchto oddělených větvích (Rosenbaum 1976, Oakes 1985). Kvalitativní př́stup ke zkoumání rozdělování žáků poukázal na nerovnost podmínek ve vzdělávání žáků. Zjištění, která přinesly tyto starší výzkumy, však mají obecnější platnost a můžeme je považovat za charakteristiku nešvarů spojených s rozdělováním žáků i dnes (jak dokládají další nedávné výzkumy). Typickými příklady je přiřazování méně kvalifikovaných učitelů nevýběrovým skupinám a naopak co možná nejlepší učitelé jsou pověřeni vyučováním ve třídách výběrových (známý to jev i z našich škol s rozšiřenou výukou jazyků či jiných předmětů). $V$ nevýběrových tř́íách, které jsou většinou složeny ze žáků pocházejících z méně podnětného rodinného zázemí, pak výzkumníci pozorovali a dokumentovali horší třídní klima, častější kázeňské problémy a z nich vyplývající zkrácený čas na výuku, ale také snížená očekávání od žáků a často nedostatečně stimulující kurikulum a nižší nároky vůči žákům ze strany učitelů, které vedly $\mathrm{k}$ celkovým horším výsledkům žáků a také $\mathrm{k}$ omezení jejich dalších vyhlídek na získání vyšších stupňů vzdělání a uplatnění se v životě. Přestože původní a průlomové práce etnografických výzkumníků byly také kritizovány za metodologické nedostatky a nebo byly zpochybněny některé jejich závěry (viz např. Slavin 1990a), nelze jim upř́t zásadní význam pro otevření problematiky a zaměření zájmu výzkumníků tímto směrem. Na jejich práce pak navazovaly četné výzkumy využívající především kvantitativních metod, včetně měření výsledků vzdělávání v různých větvích, a zjištování efektů rozdělování žáků podle schopností. Časté bylo také použití metody experimentu. Ze stovek těchto výzkumů realizovaných od 80 . let minulého století jsme informovali o zásadních zjištěních již ve dřivějších textech, které odkazují především na meta-analýzy zjištění z těchto výzkumů provedené $R$. Slavinem, A. Gamoranem, T. Lovelessem (viz Greger 2004, s. 366-368). Co tedy ř́kají výzkumy (pedagogů, psychologů i sociologů) o dopadech rozdělování žáků podle jejich schopností?

Obhájci rozdělování žáků do skupin podle jejich schopností, studijních předpokladů nebo studijních výsledků často argumentují tím, že je toto rozdělení žáků prospěšné jak pro slabší, tak i pro nadané žáky. Učitelé mohou přizpůsobit tempo výuky pomalejším žákům a věnovat se jim více, což v důsledku vede $k$ tomu, že se tito žáci naučí více, než kdyby byli vzděláváni s nadanějšími žáky společně. Argument pak nabývá na významu ve vztahu k žákům nadaným, kde je sdílená představa, že učitelé se jim nemohou $v$ běžných třídách dostatečně věnovat a tak se 
mrhá jejich potenciálem. Tyto argumenty často slýcháme $v$ rozhovorech s laickou veřejností a můžeme je považovat za sdílený prekoncept a předporozumění efektu rozdělování žáků. Dále $v$ textu ukážeme $z$ dat našeho výzkumu, jak velkou mají obdobná tvrzení podporu české veřejnosti. Nicméně nálezy pedagogických výzkumů jsou v prímém rozporu s těmito předpoklady. Výzkumy ukazují, že rozdělování žáků podle jejich schopností vede ke zhoršování průměrného výsledku vzdělávání (Gamoran a Mare 1989). Navíc dochází v průběhu odděleného vzdělávání ke zvyšování rozdílů ve výsledcích vzdělání dětí ve výběrových a nevýběrových větvích (Gamoran a Berends 1987). Zjištění z mnoha dalších výzkumů pak potvrzují, že na rozdělování žáků doplácejí především ti žáci, kteří končí v nevýběrových (nestudijních) drahách. Tito žáci dosahují mnohem lepších výsledků, když jsou vzdělávání společně s žáky s lepšími studijními výsledky (viz např. Slavin 1990b, Kerckhoff 1986). Výzkumy dále ukazují, že rozdělování žáků není jen neefektivní (tj. žádná ze skupin výrazně nezíská tím, že je vzdělávána odděleně, ale naopak slabší žáci tím výrazně tratí), ale především přispívá k růstu vzdělanostních nerovností. Ve vztahu $k$ víceletým gymnáziím tuto skutečnost potvrdily také některé analýzy dat $z$ mezinárodních šetření (Matějů, Straková 2003). V mezinárodním srovnání pak především vzdělávací systémy, které rozdělují žáky na základě schopností již v průběhu povinné školní docházky (ve věku 10 let Německo a Rakousko, a v 11ti letech ČR, Slovensko a Mad'arsko) dosahují v průměru horších výsledků, než země, které takto žáky nerozdělují. Zároveň tyto vzdělávací systémy vykazují nejvyšší závislost výsledků žáků na jejich rodinném zázemí (OECD 2001, Greger 2008). Výzkumy tedy poukazují především na nevýhody rozdělování žáků.

\section{CHARAKTERISTIKA DAT}

Analýza postojů veřejnosti k inkluzívnímu vzdělávání (resp. k rozdělování žáků = nízká podpora inkluze) byla provedena na datech z výzkumu veřejného mínění realizovaného v Ústavu výzkumu a rozvoje vzdělávání Pedagogické fakulty Univerzity Karlovy v Praze. Kvantitativní dotazníkové šetření zjištujující názory veřejnosti (1869 let) týkající se různých aspektů školního vzdělávání bylo realizováno na vzorku 1518 respondentů (z toho 1206 „běžná populace“ a 474 populace rodičovská, tj. rodiče dětí ve věku povinné školní docházky ${ }^{4}$ ). Terénní sběr dat zajištovaný agenturou MEDIAN proběhl záměrně na konci školního roku 2007/2008 (červen-srpen, 2008). Výběr respondentů byl učiněn na základě náhodného stratifikovaného výběru ve dvou základních krocích: náhodný výběr domácnosti ze seznamu adres a náhodný výběr osoby v dané domácnosti (dle tzv. Kishových tabulek). Návratnost dosáhla velmi slušné úrovně $73 \%$ (z 2080 náhodně vybraných domácností bylo úspěšně dotázáno 1518).

4 Nesoulad čísel je jen zdánlivý. Bylo provedeno celkem 1518 rozhovorů tazatele s respondenty. Základní soubor reprezentující dospělou populaci ve věku 18 až 69 let činil 1206 respondentů, z toho bylo 162 rodičů dětí, které docházejí na základní školu nebo víceleté gymnázium. K těmto jsme ještě učinili nadvýběr 312 dalších rodičů dětí v základním vzdělávání, abychom mohli analyzovat postoje rodičů také odděleně. $(1206+312=1518$, přesto celkový počet rodičů je $162+312=474)$. 
Pro sběr dat byla použita moderní technika CAPI (Computer Assisted Personal Interviewing), která spočívala v převedení dotazníku do podoby počítačového programu a následného dotazování s pomocí sítě tazatelů vybavených notebookem (program kontroluje vyplnění všech položek, odpovědi jsou zaznamenávány přímo do počítače a eliminují se tak chyby při přepisu dat, program umožňuje rotaci pořadí otázek v bateriích otázek a přináší celou řadu dalších výhod).

Výsledný datový soubor byl s pomocí standardních statistických postupů opatřen vahami na populaci České republiky podle známých kritérií (pohlaví, věk, vzdělání, region a velikost místa bydliště). Tímto postupem bylo dosaženo skutečnosti, že výsledky po zvážení odpovídají populaci České republiky. V následujícím textu pracujeme proto $s$ váženým souborem. Také populace rodičů (474 respondentů) byla opatřena separátními vahami a to tak, aby především vzdělanostní struktura odpovídala vzdělanostní populaci rodičů, která se odlišuje od průměru celé veřejnosti. Vzhledem ke skutečnosti, že jsme při konstruování výběrového souboru veřejnosti (1206) také realizovali nad-výběr rodičovské veřejnosti, budeme tak dále $v$ textu hovořit o třech populacích. Budeme-li dále $v$ textu hovořit o postojích veřejnosti, prípadně české veřejnosti, pracujeme se souborem 1206 respondentů, který je vážený tak, aby byl reprezentativní za dospělou českou populaci ve věku 18 až 69 let. Budeme-li hovořit o názorech rodičǔ, pracujeme se základním souborem 474 rodičů, přičemž rodiči označujeme ty, kteří mají dítě v povinné školní docházce a zároveň bydlí ve společné domácnosti s dítětem. Také datový soubor 474 rodičů byl opatřen vahami tak, abychom mohli zobecňovat na rodičovskou populaci v ČR. V neposlední řadě pak mnohdy porovnáváme populaci rodičů a „nerodičǔu. Označení nerodiče zde neznamená, že by se jednalo o bezdětné páry nebo bezdětné jedince, ale jedná se o zbytek populace $z$ hlavního souboru 1206 respondentů po vyjmutí těch rodičů, jejichž děti realizují povinnou školní docházku (navštěvují základní školu nebo nižší ročníky víceletých gymnázií). Ve skupině „nerodičüu, tak mohou být rodiče dětí v mateřské škole, případně na vyšších stupních vzdělání sekundární školství, nebo terciér). V základním souboru 1206 respondentů tak bylo 162 rodičů a 1044 nerodičů. Pro úspornost jazyka jsme zvolili označení nerodič, přestože je věcně zkreslující. $Z$ tohoto důvodu ho mnohdy v textu uvádíme v uvozovkách - „nerodiče". Kategorii rodičů jsme navíc omezili na rodiče povinné školní docházky (nejčastěji děti ve věku 6 až 15 let) proto, že většina našich otázek se zaměřovala na vzdělávání právě této věkové skupiny dětí.

Pro doplnění zjištění $k$ danému tématu využíváme také sekundární analýzu některých dalších výzkumů. $V$ tomto textu jde především o výzkum agentury STEM/ MARK provedeném $v$ dubnu 2009, a to pomocí face-to-face rozhovorů s 583 rodiči (výzkum byl součástí většího množství výzkumů a nese název Akce Rodina). Výzkum byl realizován na zakázku Ministerstva školství, mládeže a tělovýchovy ČR. $\checkmark$ tomto výzkumu se jednalo o rodiče žáků 9. ročníku ZŠ a odpovídajících ročníků víceletých gymnázií. 


\section{ANALÝZA POSTOJU゚ K ROZDĚLOVÁNÍ ŽÁKU゚ A INKLUZI}

V rámci reprezentativního dotazníkového šetření veřejnosti a rodičů jsme respondentům položili několik baterií otázek, které se vztahují ke vnímání spravedlivosti vzdělávacího systému. Samostatnou baterii otázek jsme věnovali percepci vývoje vzdělanostních nerovností po roce 1989, dále jsme se tázali na volbu vzdělávací dráhy žáků a bariér, které mohou zabraňovat českým občanům získat vzdělání, jaké si přejí. $V$ tomto textu se však zaměříme na analýzu pouze jedné baterie otázek (E03), která se vztahovala k rozdělování žáků v rámci povinného vzdělávání. $V$ české odborné literatuře se jedná o problematiku diferenciace, především pak rozdílů mezi pojetím vnější a vnitřní diferenciace ( $v$ anglicky psané literatuře se používají pojmy tracking nebo streaming - bliže viz Greger 2004), tedy různým formám rozdělování žáků do skupin či tříd podle jejich schopností.

Baterie 12 výroků byla uvozena textem: „Český vzdělávací systém využívá v průběhu povinné školní docházky dělení žáků do různých typů škol na základě jejich schopností. Vyjádřete svou míru souhlasu k následujícím tvrzením, která se týkají některých príkladů dělení žáků." Z jednotlivých výroků, ke kterým respondenti vyjadřovali míru souhlasu na čtyřbodové škále, 4 výroky vyjadřovaly postoje podporující rozdělování žáků do různých typů škol a tříd, tedy vnější diferenciaci. Dalších šest výroků mělo charakter podpory inkluzívního vzdělávání, tedy podpory pro společné vzdělávání různých dětí v heterogenních kolektivech, a to žáků různě nadaných. Další dva výroky pak není možné považovat a priori za výroky podporující inkluzi či exkluzi, ale jedná se o doplňující postoje respondentů k nejvýznamnějšímu a také nejdiskutovanějšímu rozdělování žáků $v$ českém vzdělávacím systému - $k$ víceletým gymnáziím (jedná se o výroky: 1. odchod některých žáků z 5. třídy ZŠ na víceletá gymnázia snižuje kvalitu základních škol; 2 . Víceletá gymnázia poskytují výrazně lepší vzdělávání než základní školy.).

Vzhledem k poměrně velkému rozsahu dotazníku se nám v předvýzkumu potvrdilo, že dotazování respondentů ve věku 60 - 69 let mnohdy trvá podstatně déle a vyžaduje větší míru soustředění. U mnoha otázek tak byla zúžena baterie otázek pro tyto respondenty. Vzhledem $\mathrm{k}$ tomu, že dále $\mathrm{v}$ textu vytváríme také index inkluze na základě odpovědí v 9 otázkách, omezili jsme pro analýzy datový soubor na populaci 18 až 59 let, tedy na ty, kteři odpovídali na všechny výroky vztahující se k rozdělování ( $N=1026)$. Následující graf prezentuje míru souhlasu české veřejnosti s výroky, které jsme označili za podporu rozdělování žáků (tedy exkluzi).

$\checkmark$ grafu č. 1 prezentujeme odpovědi české veřejnosti jako celku. Při porovnání odpovědí, ,rodičư" (tj. těch rodičů, jejichž dítě realizuje povinné vzdělávání) a „nevodičũ" (tj. těch, kteří bud' děti nemají, nebo těch, jejichž děti ještě nebo již neplní povinné vzdělávání) nebyly zaznamenány statisticky významné rozdíly až na jednu výjimku. Rodiče (průměr 2,09 na čtyřbodové škále) vyjadřovali větší míru souhlasu s tím, aby děti, které $v$ běžné základní škole nestačí ostatním, byly přeřazeny do škol speciálních, než nerodiče (průměr 2,26). 
Graf 1: Míra souhlasu české veřejnosti s výroky podporujícími rozdělování žáků na základě jejich schopností (exkluzi)

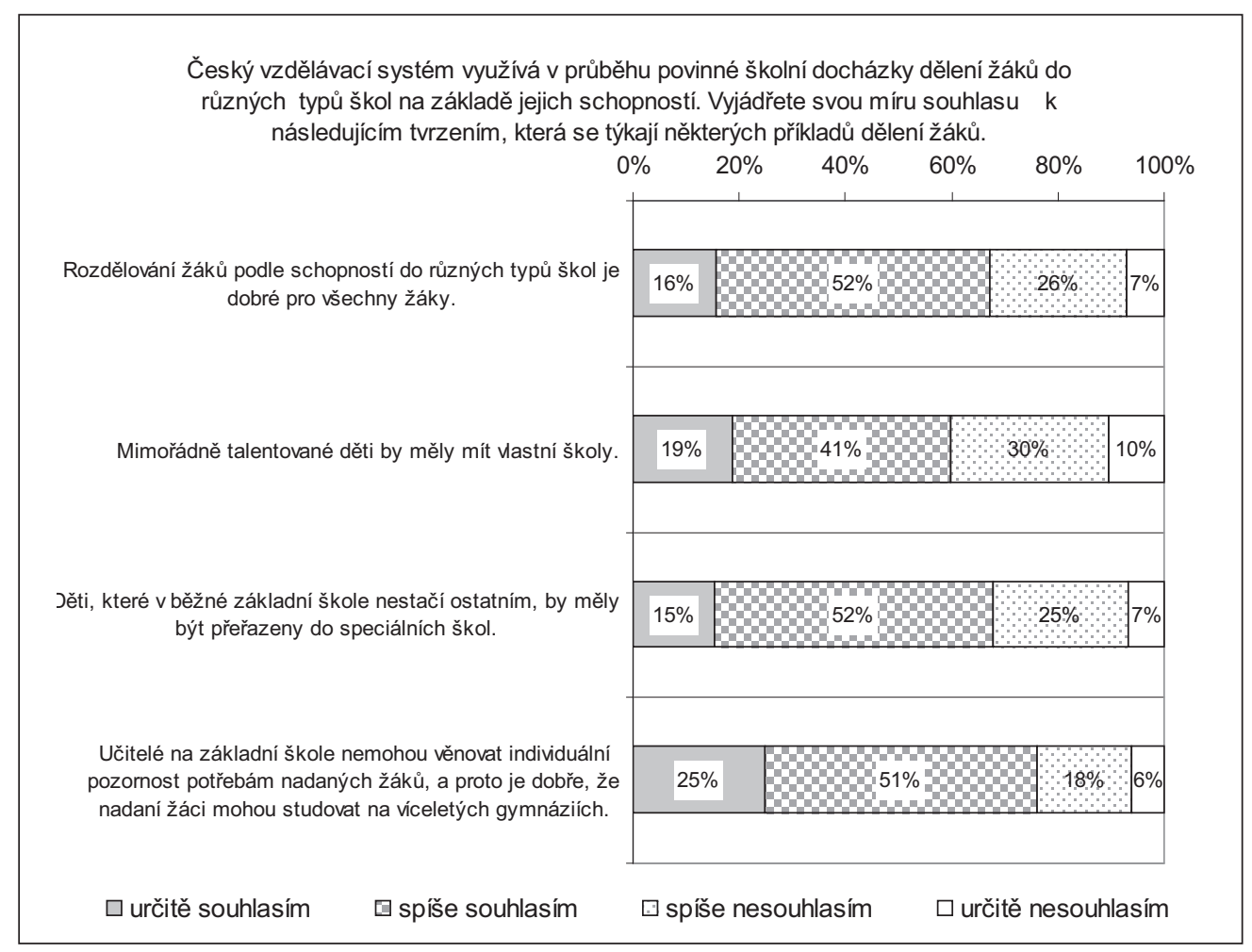

Zdroj: ÚVRV PedF UK a Medián, 2008

Přestože rodiče i nerodiče vyjadřovali zhruba stejnou míru souhlasu s tímto tvrzením (68,7\% rodičů a $67,5 \%$ nerodičů s tímto tvrzení určitě nebo spíše souhlasí), rodiče častěji volili krajní pozici „určitě souhlasím“ (26,8\% vs. $13,7 \%$ ). Rozdíly mezi oběma průměry jsou tak statisticky významné (dvou-výběrový $t$-test, $t=-2,43$, $\mathrm{p}=0,015)$, ale $v$ žádném další výroku se statisticky významně neliší názory rodičů a nerodičů. Ani tato statisticky významná odchylka však nemění nic na tom, že věcně se názory rodičů a nerodičů v podstatě neliší.

Většina rodičů i české veřejnosti je tak přesvědčena, že rozdělování žáků podle jejich schopností prospívá všem žákům, tedy těm slabším i těm nadaným, ve velké míre podporují jak zřizování škol pro nadané, tak i přeřazování „slabších“ žáků $z$ běžného proudu do škol speciálních. Většinový souhlas se čtvrtým výrokem dokládá široce sdílený předpoklad, že myšlenka oddělení nadanějších žáků na víceletá gymnázia je $v$ zásadě správným řešením, protože učitelé nemohou (či neumějí) věnovat individuální pozornost nadaným žákům. Většinová podpora výrokům

5 V grafu pro přehlednost neuvádíme podíl respondentů, kteří zvolili odpověd' nevím. Podíl respondentů, kteří volili odpověd' nevím pro tyto 4 výroky v pořadí, jak jsou uvedeny za sebou v grafu, byl: $9,6 \%, 6,5 \%, 5,2 \%$ a $6,7 \%$. 
předpokládajícím výhodnost rozdělování žáků podle schopností koresponduje s elitářskou myšlenkou, která si klade za cíl rozdělit žáky co nejdřive podle jejich schopností a poskytnout jim pak „odpovídající vzdělání". Vzdělání je tak chápáno jako rozvíjení schopností jedincům daným, vliv prostředí (i školy) a úsilí je pak považován za druhotný či zanedbatelný. Zastánci časného rozdělování žáků na „více a méně chytré" pak implicitně a nepřiznaně předpokládají výraznou podmíněnost vzdělání vrozenými schopnostmi (geneticky). Tuto skutečnost jsme však v našem výzkumu neověřovali, pro bližší porozumění postojům veřejnosti $k$ rozdělování žáků však mohou být budoucí výzkumy o tuto otázku rozšíreny.

V úvodní části tohoto textu jsme odkázali na pedagogické výzkumy, které jsou $v$ rozporu s míněním české veřejnosti i rodičů a které opakovaně potvrzují, že rozdělování žáků není odpovědí na zvyšování kvality vzdělávání, průměrné vzdělanosti, ale ani ne nutně zvyšování vzdělanostní úrovně těch nejlepších. Tento fakt je však v české veřejnosti málo znám a diskutován, což je z části dáno nedostatkem kvalitních výzkumů (především longitudinálních), které by zjištovaly efekty odděleného vzdělávání žáků různých schopností (odkazované výzkumy vycházejí převážně ze zahraničí nebo z mezinárodních výzkumů výsledků vzdělávání žáků jako je PISA, TIMSS), ale také deficitem dostatečně angažovaných výzkumníků, kteří by tato výzkumná zjištění účinně komunikovali směrem k české veřejnosti, která je přesvědčena o opaku.

Přestože naše data neumožňují mezinárodní srovnání, domníváme se, že podpora časného rozdělování žákủ je stejně rozšířená i v dalších zemích střední Evropy, které děti dělí do různých proudů vzdělávání již v průběhu povinné školní docházky (Německo, Rakousko, Mad’arsko, Slovensko). Výsledky mezinárodního výzkumu PISA, které poukázaly na neefektivnost i nespravedlivost časného rozdělování žáků, vyvolaly řadu diskusí v těchto zemích a také reakce $v$ médiích. $V$ České republice pak argumenty na podporu vnější diferenciace byly silně artikulovány především $\checkmark$ reakci na návrh sociálně-demokratického ministra školství Eduarda Zemana, který navrhoval v roce 2001 zrušit víceletá gymnázia. Diskuze v ČR i v těchto zemích tak utvrdily mnohé politiky $v$ přesvědčení, že dělení žáků si přeje většina společnosti. Ze zahraničních výzkumů ze střední Evropy pak můžeme jako příklad uvést výzkumy veřejného mínění v Mad'arsku, které rovněž opakovaně ukazují vysokou podporu veřejnosti pro vyčlenění „nadaných žákư” do speciálních škol. Trendová data z tohoto výzkumu však poukazují na skutečnost, že mad'arská veřejnost v roce 2002 (ve srovnání s předchozími šetřeními v letech 1990, 1995 a 1999) mírně oslabila podporu rozdělování žáků a naopak došlo k mírnému nárůstu respondentů, kteří se domnívají, že toto oddělování nadaných od ostatních vrstevníků je v zásadě nespravedlivé (tabulka č. 1).

Dalších šest výroků v baterii na rozdělování žáků z našeho výzkumu veřejného mínění jsme formulovali jako výroky podporující inkluzi, tedy podporu společného vzdělávání dětí v heterogenních kolektivech, dětí které se od sebe liší svými schopnostmi, ale také například sociálním či etnickým původem. Míru podpory jednotlivých „inkluzívních výroků” prezentuje graf č. 2. 
Tab. 1: Mad’arská veřejnost: Názory na oddělování nadaných žáků (procento respondentů, kteří souhlasili s jedním ze dvou výroků, resp. nedokázali na otázku odpovědět).

\begin{tabular}{|l|c|c|c|c|}
\hline & 1990 & 1995 & 1999 & 2002 \\
\hline $\begin{array}{l}\text { Nadané děti by měly být vzdělávány oddě- } \\
\text { leně ve školách pro nadané, nebot jenom } \\
\text { tak mohou svůj talent rozvíjet }\end{array}$ & $50 \%$ & $55 \%$ & $46 \%$ & $42 \%$ \\
\hline $\begin{array}{l}\text { Nadaní žáci by neměli být vzděláváni oddě- } \\
\text { leně ve školách od ostatních dětí, protože to } \\
\text { není v souladu s principem spravedlivosti. }\end{array}$ & $43 \%$ & $35 \%$ & $47 \%$ & $50 \%$ \\
\hline Nevím/nedokážu posoudit & $7 \%$ & $10 \%$ & $7 \%$ & $8 \%$ \\
\hline
\end{tabular}

Zdroj: Lannert, Mártonfi, Vágó (2004)

Graf 2: Míra souhlasu české veřejnosti s výroky podporujícími společné vzdělávání různých žáků (inkluzívní vzdělávání) ${ }^{6}$

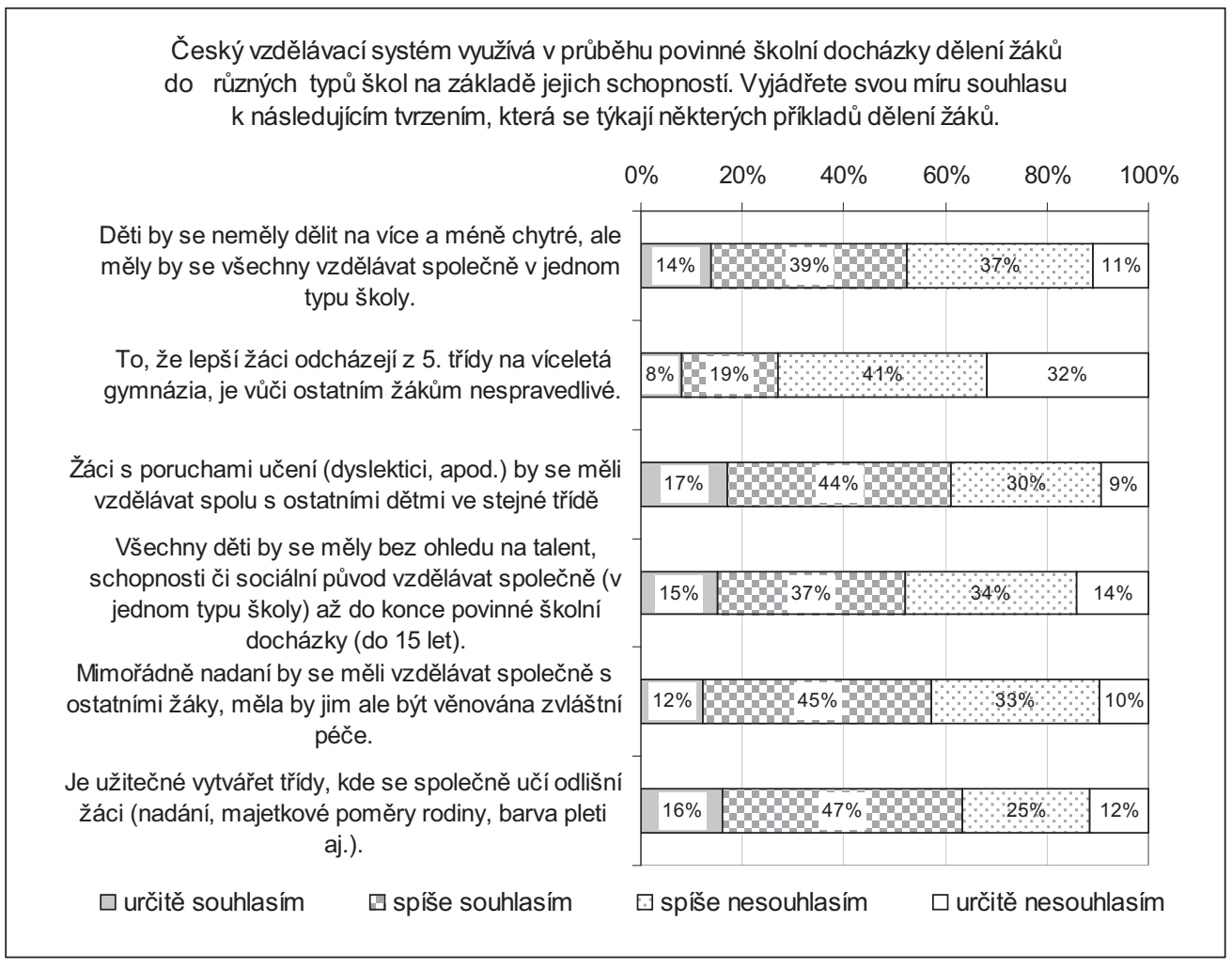

\section{Zdroj: ÚVRV PedF UK a Medián, červen až srpen 2008}

6 V grafu pro přehlednost neuvádíme podíl respondentů, kteří zvolili odpověd' nevím. Podíl respondentů, kteři volili odpověd' nevím pro těchto 6 výroků v pořadí, jak jsou uvedeny za sebou v grafu, byl: $4,7 \%, 4,3 \%, 6,6 \%, 5,2 \%, 5,3 \%$ a $5,3 \%$. 
V odpovědích na jednotlivé otázky nebyly zjištěny statisticky významné rozdíly v názorech rodičů a nerodičủ. Zatímco $v$ předchozí baterii otázek se česká veřejnost jevila jako ryze elitářská, vysoká podpora inkluzívním výrokům jednoznačné vnímání české společnosti jako elitářské nahlodává. Vůči výroku, že odchod některých žáků na víceletá gymnázia je nespravedlivý vůči ostatním, se ohradila velká část respondentů (zhruba třetina respondentů přitom volila krajní polohu „určitě nesouhlasím"), ale všechny ostatní inkluzívní výroky mají většinovou podporu veřejnosti i rodičů. Většina veřejnosti i rodičů tak souhlasí s tím, že je užitečné vytvářet třídy, kde se společně učí odlišní žáci - nejen žáci různých schopností, ale také žáci z různých rodinných poměrů. Zvláště dva výroky jsou pak z hlediska inkluze významné, a to výrok, že všechny děti by se měly bez ohledu na talent, schopnosti či sociální původ vzdělávat společně ( $v$ jednom typu školy) až do konce povinné školní docházky (do 15 let) a názor, že děti by se neměly dělit na více a méně chytré, ale měly by se všechny vzdělávat společně v jednom typu školy. Nicméně můžeme říct, že $v$ odpovědi na tyto otázky je společnost rozdělena na zhruba dvě stejně velké poloviny, kdy jedna s danými výroky souhlasí a druhá nikoliv (souhlas s těmito výroky vyjadřovalo $52 \%$ resp. $53 \%$ veřejnosti). Naopak výroky podporující rozdělování žáků (viz graf č. 1) získaly mnohem větší podporu veřejnosti (od $60 \%$ do $76 \%$ respondentů s nimi vyjádřilo souhlas). $Z$ mnohem větší mírou souhlasu s výroky podporujícími rozdělování žáků můžeme usuzovat, že tento názor v české veřejnosti převládá. Nicméně stejně tak vidíme, že velká část veřejnosti (polovina respondentů) vyslovuje také souhlas s výhodami společného vzdělávání odlišných žáků.

\section{NAKOLIK JSOU POSTOJE VEŘEJNOSTI K INKLUZÍVNÍMU VZDĚLÁVÁNÍ UJASNĚNÉ A ODPOVĚDI RESPONDENTU゚ NA BATERII VÝROKŮ KONZISTENTNII?}

Nabízí se tedy otázka, nakolik jsou postoje české veřejnosti k inkluzívnímu vzdělávání konzistentní. První ověření konzistence odpovědí respondentů na otázky inkluze se nabízí z porovnání odpovědí na výroky, které chápeme jako protikladné. $Z$ baterie deseti výroků se jako nejlepší príklad výroků, které si odporují, jeví výroky ve vztahu ke vzdělávání mimořádně nadaných žáků: E03 c) Mimořádně nadané děti by měly mít vlastní školy a E03 k) Mimořádně nadaní by se měli vzdělávat společně s ostatními žáky, měla by jim ale být věnována zvláštní péče. Zatímco výrok E03c považujeme za výrok podporující exkluzi, tedy oddělené vzdělávání nadaných žáků od žáků ostatních, naopak výrok E03k otevřeně deklaruje společné vzdělávání nadaných žáků s ostatními, nicméně s promyšlenou vnitřní diferenciací a péčí o nadané v rámci heterogenních žákovských kolektivů. Předpokládali bychom tedy, že konzistentně odpovídali ti respondenti, kteří vyslovili souhlas s jedním a nesouhlas s druhým výrokem a opačně. Kolik takových respondentů bylo?

Konzistentní podporu oddělenému vzdělávání mimořádně nadaných žáků ve vlastních školách vyjádřilo 30 \% respondentů (to jsou ti, kteří souhlasili s tím, že 
mimořádně nadaní mají mít vlastní školy a zároveň vyjádřili nesouhlas s výrokem, který navrhoval společné vzdělávání nadaných žáků s ostatními žáky při důrazu na zvláštní péči pro nadané). Za konzistentní považujeme taky výroky 27 \% respondentů, kteři vyslovili podporu společnému vzdělávání mimořádně nadaných žáků spolu s ostatními a zároveň odmítli, že by měli mít tyto děti vlastní školy. Zůstává nám pak $43 \%$ respondentů, kteří odpověděli na první pohled nekonzistentně - tj. vyslovili souhlas (resp. nesouhlas) s oběma protichůdnými výroky. Při prvním pohledu by se tak dalo usuzovat, že velká část veřejnosti nemá na tuto otázku ujasněné názory. Tento závěr však nemůžeme jednoduše vyslovit už proto, že jeden výrok není negací druhého výroku. Přestože jeden výrok podporuje vytváření škol pro nadané žáky a tedy jejich oddělené vzdělávání a druhý výrok navrhuje společné vzdělávání nadaných s ostatními dětmi, oba výroky mají ještě jedno společné. $\mathrm{K}$ výroku, který navrhuje společné vzdělávání nadaných s ostatními, je připojen ještě dodatek (či podmínka), že těmto žákům má být věnována zvláštní péče. A tak můžeme interpretovat postoje téměř třetiny respondentů (29\%), kteři vyslovili souhlas s výrokem „mimořádně nadaní žáci by měli mít vlastní školy" a zároveň souhlasili s výrokem, že mají být tito žáci vzdělávání společně s ostatními, ale má jim být věnována zvláštní péče, jako postoj, který zdůrazňuje, že se má pro mimorádně nadané něco dělat (at již to bude zvýšená péče ze strany učitele, nebo př́mo vytváření speciálních škol pro nadané). Pokusili jsme se tedy ještě podívat na jiné otázky v dalších částech dotazníku, na které tito respondenti odpovídali a které se týkaly vzdělávání mimořádně nadaných žáků. $V$ dotazníku byla obecná otázka, zda "České školství dostatečně rozvíjí schopnosti mimořádně nadaných žákư" a dále baterie otázek ve vztahu k problémům školy („Naše základní školy se mohou potýkat s různými problémy. Jak vážné jsou podle Vás ty následující?", škála: 1=velmi vážný, $2=$ poměrně vážný, $3=$ =nepř́liš vážný, $4=$ není problém, $9=$ nedokážu posoudit), přičemž jeden z problémů byl formulován jako „nedostatečný rozvoj talentovaných a nadaných žáků.". Předpokládali jsme, že respondenti, jejichž postoje si můžeme alternativně vysvětlit jako postoje, které požadují, aby se pro nadané žáky "něco dělalo" (tj. oněch $29 \%$ respondentů, kteř́ odpověděli, že mimořádně nadaní mají mít vlastní školy, a zároveň souhlasili s tím, že mají být vzděláváni s ostatními, ale má jim být věnována zvláštní péče), budou vnímat větší nedostatek českého školství v podpoře vzdělávání mimořádně nadaných žáků. Nicméně tento předpoklad se nepotvrdil. Většina ( $68 \%$ ) těchto respondentů souhlasila s výrokem, že české školství dostatečně rozvíjí schopnosti mimořádně nadaných žáků a tato míra souhlasu se výrazně nelišila od celkového postoje veřejnosti, kde s tímto výrokem souhlasilo celkem $65 \%$ respondentů. Tato skupina respondentů však vnímala "nedostatečný rozvoj talentovaných a nadaných žáků" mírně častěji jako velmi vážný problém základních škol než v průměru česká veřejnost (jako velmi vážný uvedlo tento problém $17 \%$ proti $12 \%$ české veřejnosti).

Analýzu odpovědí respondentů na dva výroky ve vztahu ke vzdělávání mimorádně nadaných žáků tak můžeme shrnout tvrzením, že respondenty můžeme přiřadit do tří skupin. Dvě zhruba stejně velké skupiny ( $27 \%$ a $30 \%$ respondentů) se jeví ve svých odpovědích na oba výroky jako jednoznačně konzistentní, a to jedna 
skupina ve směru podpory vzdělávání nadaných žáků spolu s ostatními a druhá zase podporuje jejich vzdělávání odděleně od ostatních. Postoje větší skupiny respondentů (43\%) je pak obtížné interpretovat. Bud' je můžeme vnímat jako odporující si a tedy nekonzistentní a můžeme tak říci, že velká část respondentů nemá názory na vzdělávání nadaných žákủ nijak ujasněné a odpovídala nahodile (připomeňme, že respondenti měli možnost u každé otázky zvolit možnost nevím/nedokážu posoudit, tuto možnost zvolilo v každé otázce od 4 do $6 \%$ dotazovaných). Druhá možná interpretace pro větší část respondentů, kteří souhlasili s oběma výroky, je, že tito respondenti zdůrazňovali volbou odpovědí obecnější názor, že se vzdělávání mimořádně nadaných žáků má věnovat zvýšená pozornost, at' již to bude formou vytváření škol pro mimořádně nadané, anebo zvýšenou péči učitelů, nicméně srovnání odpovědí těchto respondentů na jiné otázky o nadaných žácích tuto druhou interpretaci př́liš nepodpořily.

Podobně jako v předchozím príkladu můžeme pohlížet i na další dvojici výroků, která se jeví být protikladná. Z dalších výroků E03 d) Děti, kterév běžné základní škole nestači ostatním, by měly být prěrazeny do speciálních škol. a E03h) Žáci s poruchami učení (dyslektici, apod.) by se měli vzdělávat spolu s ostatními dětmi ve stejné třídě.7 Oproti předchozím výrokům týkajících se mimořádně nadaných žáků, se naopak tyto dva výroky týkají žáků spíše problémových, to je těch, kteří nestačí ostatním svým spolužákům a v učení jsou pomalejší, nebo žáků s diagnostikovanou dys-poruchou. Také při následující analýze nás zajímalo, jak velká je skupina těch, kteří odpovídají konzistentně na oba výroky. Také tato analýza výroků potvrdila, že velká část respondentů odpovídá do jisté míry nekonzistentně. Konzistentně na podporu společného vzdělávání těchto „pomalejších“ žáků s ostatními dětmi (tj. rozhodně nebo spíše nesouhlasili s výrokem E03d a rozhodně/spiše souhlasili s výrokem E03h) vypovídalo $29 \%$ respondentů. O něco menší podíl respondentů $(23 \%)$ vypovídal naopak konzistentně ve smyslu jejich odděleného vzdělávání od ostatních "bystřejších" spolužáků (tj. rozhodně či spíše souhlasili s výrokem E03d a zároveň rozhodně/spíše nesouhlasili s výrokem E03h). Téměř polovina respondentů (48\%) však opět odpovídala do jisté míry nekonzistentně, tj. souhlasili či nesouhlasili s oběma výroky současně, přestože je teoreticky považujeme za protikladné (E03d je výrok podporující exkluzi a E03h je naopak výrokem inkluzívním). Velká většina těchto nekonzistentních respondentů ( $86 \%)$ přitom souhlasila s tím, aby žáci, kteří nestačí ostatním, byli přeřazeni do speciálních škol, zároveň však souhlasila s výrokem, že žáci s poruchami učení by se měli vzdělávat ve stejné tř́ídě s ostatními dětmi.

Hlavním cílem uvedené analýzy bylo poskytnout hlubší vhled na míru konzistentnosti v odpovědích respondentů a tedy i na to, nakolik mưžeme postoje veřej-

$7 \mathrm{~K}$ analýze protikladnosti těchto výroků nás vedl návrh jednoho z recenzentů, který poukázal na protikladnost těchto dvou výroků a tázal se, zda míra konzistence v odpovídání na tyto dva výroky byla obdobná, jako u výroků vztahujících se k mimořádně nadaným žákům. Příklad těchto dvou výroků se naopak váže ke vzdělávání žáků „problémových“, žáků z opačného spektra pomyslné škály školní úspěšnosti, tedy žáků, kteří nestačí tempu většiny či žákưm s dys-poruchami. Navíc také tato analýza podporuje a dokresluje teoretickou nekonzistentnost odpovědí poměrně značné části respondentů, proto jsme ji dodatečně do textu zařadili. 
nosti k inkluzívnímu vzdělávání považovat za ujasněné a vyhraněné. Dále v textu budeme tuto otázku ověřovat i na celé baterii 10 výroků s pomocí koeficientu vnitřní konzistence a konstruováním sumačního indexu inkluze 8 .

V souvislosti $s$ tématem vzdělávání nadaných žáků ještě uved'me, že výzkum agentury STEM/MARK provedený v dubnu 2009 pro MŠMT ČR na vzorku 583 rodičů zjistil, že většina rodičů (61\%) si myslí, že je možné rozvíjet a podporovat u jedince výjimečné nadaní i v rámci širšího kolektivu běžné třídy, kde jsou děti rozmanitých schopností. To je $v$ souladu $s$ názorem veřejnosti i rodičů zjištěným $v$ našem výzkumu, kde $57 \%$ z celkového počtu 474 rodičů a $57 \%$ z 1025 respondentů z řad širší veřejnosti rovněž vyjádřilo podporu výroku, že mimořádně nadaní by se měli vzdělávat společně s ostatními žáky, měla by jim ale být věnována zvláštní péče.

Stále však před námi zůstává otevřená otázka, nakolik veřejnost a rodiče odpovídají konzistentně (spíše na podporu inkluze nebo spíše na podporu exkluze) $\checkmark$ baterii uvedených deseti výroků. Z odpovědí respondentů na inkluzívní výroky uvedené $v$ grafu č. 2 se pak ukazuje, že často respondenti většinově vyjadřují podporu inkluzi, ale stejně tak podporovali ještě v mnohem větší miŕ̌e rozdělování žáků (graf č. 1). Už jsme se věnovali hlubší analýze názorů respondentů, kteří vyjadřovali většinovou podporu výroku "mimořádně nadané děti mají mít vlastní školy" (60\% veřejnosti určitě/spíše souhlasí) a zároveň stejně velkou podporu pro výrok, že by se mimořádně nadaní měli vzdělávat společně s ostatními, měla by jim ale být věnována zvláštní péče ( $57 \%$ určitě/spíše souhlasí). Nicméně podobnou míru souhlasu s výroky, které si spiše odporují, můžeme vidět i v dalších případech. $V$ prípadě víceletých gymnázií bylo nabídnuto odůvodnění jejich existence tím, že učitelé na základních školách nemohou věnovat individuální podporu nadaným žákům, a s tímto zdůvodněním souhlasily tři čtvrtiny respondentů, prìtom však většina veřejnosti $(57 \%)$ zároveň podpořila myšlenku společného vzdělávání mimořádně nadaných žáků s ostatními vrstevníky za předpokladu věnování zvláštní péče. Stejně tak jako $67 \%$ respondentů souhlasilo (určitě nebo spíše souhlasilo) s tím, aby žáci, kteří ostatním nestačí, byli přeřazeni do speciálních škol, také většina české veřejnosti (61\%) podporuje myšlenku, že by se žáci s poruchami učení (dyslektici apod.) měli vzdělávat ve společné trí́dě s ostatními žáky. Stejně tak obecnější výroky o tom, že je žáky třeba vzdělávat v jednom typu školy a ne je oddělovat, že je užitečné vytvářet třídy, kde se žáci v mnoha ohledech liší, a jinak formulovaná otázka na společné vzdělávání žáků do 15 let (tedy v rozporu se současnou praxí) získaly většinovou podporu veřejnosti, přestože jsou v rozporu s výroky exkluzivními, ve kterých veřejnost vyslovovala podporu s rozdělováním žáků podle schopností.

8 Při konstrukci souhrnného indexu budeme pracovat s původními 10 výroky, které jsme představili v předchozích částech textu. Při provádění analýz potřebných pro tvorbu indexu se však ukázalo, že jedna položka (výrok) nijak nepřispívala k výpovědní hodnotě indexu, naopak jeho sílu (vnitřní konzistenci) oslabovala, a proto byla na základě analýz vyloučena z tvorby indexu (viz zvýrazněný řádek v tabulce č. 2). Finální index inkluze, který představujeme dále v textu, je tak složen pouze z 9 výroků. Na tento zdánlivý nesoulad (jednou hovoříme o indexu z 10ti výroků, podruhé z 9ti výroků) proto čtenáře upozorňujeme. Náš pưvodní záměr byl konstruovat index ze všech výroků, nicméně analytické postupy ukázaly, že je zapotřebí pracovat pouze s devíti výroky, jak dále v textu vysvětlujeme. 
Srovnání odpovědí na jednotlivé výroky na podporu inkluzívního vzdělávání i rozdělování žáků tak před námi otevírají otázku, zda má veřejnost $v$ daných věcech jasno, zda si skutečně něco „konzistentně“ myslí, a zda je možné ji považovat za více či méně inkluzívní nebo naopak elitářskou. První otázkou, kterou jsme si položili, je zda na jednotlivé výroky, které vyjadřují podporu spíše inkluzi nebo exkluzi, respondenti odpovídali podobně (zda spolu vzájemně korelují). Za tímto účelem jsme ověřovali reliabilitu celé škály deseti výroků pomocí koeficientu vnitřní konzistence Cronbachovo $a^{9}$. $Z$ deseti výroků v baterii otázek bylo 6 výroků na podporu inkluzívního vzdělávání (viz prvních 6 výroků v tabulce č. 2) a následující 4 výroky byly negativní směrem k inkluzi, tedy výroky podporující exkluzi. U těchto čtyřech výroků bylo zapotřebí překódovat proměnné tak, aby vyjadřovaly jeden směr (vyšší hodnota znamená podpora inkluze - to znamená že u inkluzívních výroků má krajní poloha "určitě souhlasím" hodnotu 4, a u výroků podporujících rozdělování naopak hodnotu 1). Pro 10 uvedených výroků je Cronbachovo $a=0,729$. Tato hodnota koeficientu vnitřní konzistence je většinou autorů považována za uspokojivou pro tvorbu sumačních indexů a podporuje tedy náš předpoklad, že za všemi těmito výroky se skrývá latentní (př́mo neměřitelný) konstrukt inkluze (při otočení škály bychom mohli hovořit o indexu exkluze ${ }^{10}$ ). Můžeme tedy ř́ci, že jak rodiče, tak i veřejnost $v$ baterii deseti výroků se vyjadřovali ve velké míře $k$ podobným věcem, k inkluzi vzdělávání a jejich postoj $k$ inkluzi tak můžeme vyjádřit pomocí jednoho čísla, indexu inkluze.

9 Tvorba sumačních indexů je popsána v četné metodologické literatuře a je hojně používána v zahraničí. U nás se nicméně s tímto přístupem př́liš nesetkáváme (zpravidla jen v zahraničních výzkumech). S indexy se nejčastěji pracuje pouze v rámci analýzy dat baterií výroků, nicméně tvorba indexu by měla být rozmyšlena již při prípravě dotazníku. V našem výzkumu, který si kladl za cíl především zmapovat názory veřejnosti na mnoho oblastí vzdělávání a školství tak otázky na časné rozdělování žáků tvořily pouze jednu z mnoha baterií otázek a vzhledem k rozsáhlosti celého výzkumu tak nebylo ani možno realizovat tvorbu sumačního indexu od počátku podle navržených postupů, kdy zpravidla připravovaný index je hlavním tématem celého výzkumu a dotazníku. Správný metodologický postup při tvorbě sumačních indexů popsali např. DeVellis 2003, Spector 1992 a Clarková a Watson 1995. Zájemce o tuto problematiku odkazujeme na tyto práce. Domníváme se, že tvorba sumačních indexů (nikoliv ad hoc, ale jejich promyšlená konstrukce od počátku) mưže výrazně přispět ke kvalitě dotazníkových šetření v ČR a také $k$ hlubšímu porozumění zkoumaným jevům.

10 Otočení škály je arbitrárním rozhodnutím výzkumníka. Mohli jsme stejně tak otočit škály a hovořit o indexu exkluze, kdy vyšší hodnota by naopak vyjadřovala vyšší podporu rozdělování žáků různých schopností. Vzhledem k názvu článku (jak doporučoval jeden z recenzentů), i vzhledem k převažujícím názorům české veřejnosti by bylo možné hovořit právě o indexu exkluze. Nicméně přesto jsme se rozhodli pro tvorbu indexu inkluze, kdy vyšší hodnota znamená podporu společného vzdělávání. Bylo tomu ze dvou důvodů: 1 . důvod praktický - větší počet výroků ( 6 z 10) byl inkluzívní, proto stačilo překódovat menši část výroků; 2. důvod, důležitější, teoretický - základní teoretická literatura popisuje obrat ve vývoji společnosti k integraci a v kontextu vzdělávání pak k inkluzívnímu vzdělávání (pro přehled viz např. Greger 2006). Zároveň hovoří o inkluzi jako o morálním i empiricky podloženém požadavku na současné vzdělávání. 
Tab. 2: Analýza reliability (vnitřní konzistence) škály postojů k inkluzi (všech 10 výroků)

\begin{tabular}{|c|c|c|c|c|c|}
\hline & 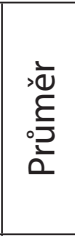 & 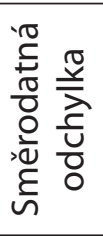 & $z$ & 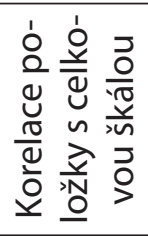 & 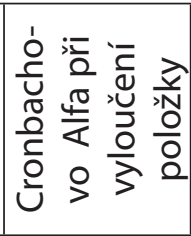 \\
\hline $\begin{array}{l}\text { Děti by se neměly dělit na více a méně } \\
\text { chytré, ale měly by se všechny vzdělávat } \\
\text { společně v jednom typu školy. }\end{array}$ & 2,5 & 872 & 811 & 431 & 701 \\
\hline $\begin{array}{l}\text { To, že lepší žáci odcházejí z 5. třídy na ví- } \\
\text { celetá gymnázia, je vǔči ostatním žákům } \\
\text { nespravedlivé. }\end{array}$ & 2,1 & 918, & 811 & 456 & 697, \\
\hline $\begin{array}{l}\text { Žáci s poruchami učení (dyslektici, } \\
\text { apod.) by se měli vzdělávat spolu } \\
\text { s ostatními dětmi ve stejné tř́lě. }\end{array}$ & 2,7 & 869 & 811 & 363, & 712 \\
\hline $\begin{array}{l}\text { Všechny děti by se měly bez ohledu } \\
\text { na talent, schopnosti či sociální původ } \\
\text { vzdělávat společně (v jednom typu ško- } \\
\text { ly) až do konce povinné školní docházky } \\
\text { (do } 15 \text { let). }\end{array}$ & 2,5 & 924 & 811 & 595, & 672, \\
\hline $\begin{array}{l}\text { Mimořádně nadaní by se měli vzdělávat } \\
\text { společně s ostatními žáky, měla by jim } \\
\text { ale být věnována zvláštní péče. }\end{array}$ & 2,6 & 826 & 811 & 402 & 706 \\
\hline $\begin{array}{l}\text { Je užitečné vytvářet třídy, kde se spo- } \\
\text { lečně učí odlišní žáci (nadání, majetkové } \\
\text { poměry rodiny, barva pleti aj.). }\end{array}$ & 2,7 & 889, & 811 & 078, & 756, \\
\hline $\begin{array}{l}\text { Rozdělování žáků podle schopnos- } \\
\text { tí do různých typů škol je dobré pro } \\
\text { všechny žáky. }\end{array}$ & 2,2 & 771 & 811 & 506, & 692, \\
\hline $\begin{array}{l}\text { Mimořádně talentované děti by měly } \\
\text { mít vlastní školy. }\end{array}$ & 2,3 & 889, & 811 & 420 & 703, \\
\hline $\begin{array}{l}\text { Děti, které v běžné základní škole ne- } \\
\text { stačí ostatním, by měly být přeřazeny } \\
\text { do speciálních škol. }\end{array}$ & 2,2 & 801 & 811 & 274 & 725 \\
\hline $\begin{array}{l}\text { Učitelé na základní škole nemohou } \\
\text { věnovat individuální pozornost potře- } \\
\text { bám nadaných žákủ, a proto je dobře, že } \\
\text { nadaní žáci mohou studovat na vícele- } \\
\text { tých gymnáziích. }\end{array}$ & 2,1 & 836, & 811 & 393, & 708, \\
\hline
\end{tabular}


Pro tvorbu indexů je doporučováno, aby Cronbachovo a bylo větší než 0,7, což $v$ tomto případě bylo dodrženo při využití všech 10 výroků. Nicméně pro větší spolehlivost tvořeného konstruktu jsme se rozhodli před vlastní tvorbou „,indexu inkluze“ vyřadit ze škály položku "Je užitečné vytvářet třídy, kde se společně učí odlišní žáci (nadání, majetkové poměry rodiny, barva pleti aj.)", která vykazovala nízkou korelaci s celkovou škálou (viz podrobnější statistika analýzy reliability v tab. č. 2). Výsledný koeficient vnitřní konzistence Cronbachovo a pro škálu skládající se z 9 položek ( 5 položek pro inkluzi a 4 výroky podporující rozdělování žáků, tj. exkluzi) tak je $a=0,756$.

Při tvorbě sumačních indexů nás však také kromě analýzy vnitřní konzistence celkové škály (všech výroků, z nichž je index vytvářen) zajímá, zda škála měří konstrukt jedno- nebo více-dimenzionální. Toto ověřujeme pomocí explorační faktorové analýzy ${ }^{11}$, která je zároveň považována za jeden ze způsobů validizace sumačních indexů (Spector 1992). Faktorovou analýzu jsme tedy provedli na 9 výrocích, které jsme využili při tvorbě indexu. Barlettův test sféricity $(p<0.001)$ i Kaiser-Mayer-Olkinova míra adekvátnosti výběru $(K M O=0,79)$ indikovaly vhodnost použití faktorové analýzy. Faktorová analýza extrahovala 2 faktory ${ }^{12}$, které společně vysvětlují 51 \% variance. Rozdělení položek do faktorů odpovídá našemu teoretickému rozdělení výroků na výroky exkluzivní a inkluzívní. Jeden faktor tak můžeme považovat za faktor společného vzdělávání různých žáků (nebo faktor inkluze, sycený pěti položkami) a druhý faktor můžeme nazvat rozdělování žáků (exkluze, sytí jej čtyři položky). Také faktorová analýza potvrdila naše teoretické chápání dvou dimenzí sledovaného latentního konstruktu - inkluze a exkluze (tak byly výroky vytvářeny pro tuto baterii již při tvorbě dotazníku s oporou o teoretické poznání v dané oblasti). Tabulka č. 3 prezentuje výsledky faktorové analýzy a také analýzy reliability (cronbachovo a dvou dílčích sub-škál indexu inkluze).

Jak vyplývá z faktorové analýzy (přestože vysvětlené procento variance není nijak osInivé), jednotlivé výroky byly přiřazeny ke dvěma faktorům - faktor společného vzdělávání a faktor rozdělování žáků - tak, jak jsme výroky formulovali při tvorbě dotazníku. Také dílčí škály pro tyto dva faktory jsou mírně nad doporučovanou hranicí pro reliabilitu škál vyjádřenou koeficientem vnitřní konzistence $(\alpha>0,7)$. Můžeme tedy říci, že také faktorová analýza i vnitřní konzistence dílčích subškál ukazuje, že respondenti odpovídali do jisté míry podobně ve vztahu ke čtyřem výrokům, které jsme označili jako exkluzivní (podporující rozdělování žáků) i ke skupině pěti výroků inkluzívních.

11 Následující část ověřující kolik dimenzí se skrývá v indexu inkluze je doplněna na základě doporučení recenzentů. Jedná se však již o metodologickou diskusi, která vzhledem k zaměření tohoto článku neumožňuje plně odpovědět na všechny otázky spojené s tvorbou sumačních indexů, přesto se pokusíme stručně vysvětlit, proč jsme se rozhodli pro tvorbu jednoho indexu o dvou dimenzích, namísto dvou oddělených indexů. Čtenáře se zájmem o tuto problematiku pak dále odkazujeme na metodologickou literaturu k tomuto tématu, uvedenou i v tomto textu.

12 Oba extrahované faktory tyto měly vlastní hodnoty (eigenvalues) > 1, také analýza scree grafu podporovala dvoufaktorové řešení. Použita byla metoda hlavních komponent a rotace varimax. 
Tab. 3: Matice faktorových zátěží

\begin{tabular}{|c|c|c|}
\hline & $\begin{array}{c}\text { Faktor } 1 \\
\text { společné } \\
\text { vzdělávání }\end{array}$ & $\begin{array}{l}\text { Faktor } 2 \\
\text { rozdělování } \\
\text { žáků }\end{array}$ \\
\hline $\begin{array}{l}\text { Děti by se neměly dělit na více a méně chytré, ale } \\
\text { měly by se všechny vzdělávat společně } v \text { jednom } \\
\text { typu školy. }\end{array}$ & ,734 &,- 040 \\
\hline $\begin{array}{l}\text { To, že lepší žáci odcházejí z 5. třídy na víceletá gymná- } \\
\text { zia, je vǔči ostatním žákům nespravedlivé. }\end{array}$ & ,599 &,- 249 \\
\hline $\begin{array}{l}\text { Žáci s poruchami učení (dyslektici, apod.) by se měli } \\
\text { vzdělávat spolu s ostatními dětmi ve stejné tř́ídě. }\end{array}$ & ,508 &,- 111 \\
\hline $\begin{array}{l}\text { Všechny děti by se měly bez ohledu na talent, schop- } \\
\text { nosti či sociální pưvod vzdělávat společně ( } v \text { jednom } \\
\text { typu školy) až do konce povinné školní docházky } \\
\text { (do } 15 \text { let). }\end{array}$ & ,762 &,- 262 \\
\hline $\begin{array}{l}\text { Mimořádně nadaní by se měli vzdělávat společně } \\
\text { s ostatními žáky, měla by jim ale být věnována zvlášt- } \\
\text { ní péče. }\end{array}$ & ,736 & ,042 \\
\hline $\begin{array}{l}\text { Rozdělování žáků podle schopností do různých typů } \\
\text { škol je dobré pro všechny žáky. }\end{array}$ &,- 208 & ,792 \\
\hline $\begin{array}{l}\text { Mimořádně talentované děti by měly mít vlastní ško- } \\
\text { ly. }\end{array}$ &,- 130 & ,757 \\
\hline $\begin{array}{l}\text { Děti, které v běžné základní škole nestačí ostatním, by } \\
\text { měly být přeřazeny do speciálních škol. }\end{array}$ & ,002 & ,636 \\
\hline $\begin{array}{l}\text { Učitelé na základní škole nemohou věnovat individu- } \\
\text { ální pozornost potřebám nadaných žáků, a proto je } \\
\text { dobře, že nadaní žáci mohou studovat na víceletých } \\
\text { gymnáziích. }\end{array}$ &,- 166 & ,713 \\
\hline$\%$ rozptylu & 26,3 & 25,1 \\
\hline kumulativní \% rozptylu & 26,3 & 51,4 \\
\hline $\begin{array}{l}\text { Cronbachovo a } \\
\text { (pro položky sytící daný faktor, tj. tučně vyznačené hodno- } \\
\text { ty faktorových zátěží v každém sloupci) }\end{array}$ & 0,709 & 0,722 \\
\hline
\end{tabular}

Pozn.: Použita byla metoda hlavních komponent a rotované řešení s podmínkou varimax.

Faktorová analýza tak ukázala na struktur dat, kdy jednotlivé výroky můžeme přiřadit ke dvěma různým faktorům. Přesto však preferujeme tvorbu jednoho souhrnného sumačního indexu namísto dvou oddělených indexů inkluze a exkluze. K tomuto rozhodnutí nás vede především vnitřní konzistence celkové škály 9ti položek, teoretická východiska při tvorbě škály, ale také vzájemná korelovanost dvou dílčích indexů-subškál $(r=0,334, p<0,001)$, i obecnější analýza korelační matice 
všech devíti výrokư ${ }^{13}$. Zásadní pak je, že práce se dvěma separátními indexy nepřinášela žádnou interpretační výhodu a hlubší porozumění struktuře naměřených postojů. Dále $v$ textu tedy pracujeme $s$ indexem inkluze tvořeným ze všech devíti výroků a analyzujeme vztah indexu k dalším relevantním proměnným.

\section{INDEX INKLUZE}

Pro další pohled na názory veřejnosti jsme proto z jednotlivých otázek konstruovali „index inkluze“. Z devíti vybraných položek (4 výroky pro exkluzi a 5 výroků inkluzívních) jsme zkonstruovali index inkluze. Jak jsme již uvedli výše, položky byly překódovány tak, aby vyjadřovaly jeden směr, tedy vyšší hodnota znamenala větší podporu inkluzívnímu vzdělávání. Index inkluze jsme vytvořili jako aritmetický průměr odpovědí respondenta na 9 otázek. Čím je hodnota indexu vyšší, tím je vyšší i podpora respondenta inkluzi; naopak nižší hodnota indexu znamená spiše podporu rozdělování žáků (jedná se o průměr položek na čtyřbodové škále, tedy minimum $=1$ a maximum $=4$ ).

Pomocí indexu inkluze můžeme interpretovat postoje české veřejnosti k rozdělování žáků souhrnně, jinak než pomocí dílčích otázek, kterou jsme provedli v před-

13 Vzhledem k připomínkám recenzentů i ke skutečnosti, že indexy jsou v pedagogickém výzkumu užívány zřídka, dovolíme si delší metodologický exkurz zdůvodňující námi zvolené řešení prezentovat souhrnný index inkluze (ze všech devíti výroků) namísto dvou indexů dílčích (indexu exkluze - 4 výroky a indexu inkluze - 5 výroků). Zaprvé je třeba zdůraznit, že teoretická východiska podporuji úvahu, že inkluze a exkluze jsou dva konce téhož kontinua a s tímto záměrem byla také baterie otázek vytvářena. Z metodologického hlediska pak považujeme za oprávněné pracovat s jedním celkovým indexem. Jednak proto, že reliabilita (Cronbachovo $\alpha$ celkové škály je 0,756 , dále proto, že celková analýza korelační matice všech položek (blíže k tomu viz Clarková a Watson 1995) naznačuje korelovanost položek také mezi oběma subškálami (to odpovídá jednak nižší vysvětlené varianci pomocí provedené faktorové analýzy (51 \%), také se ukazuje ve vzájemné korelovanosti obou dílčích škál (exkluze a inkluze, $r=0,331, p<0,001$ ). Metodologové podporují tvorbu separátních indexů především tehdy, když celá škála nevykazuje vnitřní konzistenci (např. Spector 1992, Clarková a Watson 1995). Clarková a Watson navíc zjistili, že 70 \% jimi analyzovaných studií pracovalo s dílčími subškálami, (tj. při zachování celkové škály a jejího číselného vyjádření, cílem prezentování subškál pak je především porozumění obecnému konceptu a taky pro další použití jinými výzkumníky, kteří by měli ověřit, zda struktura jejich dat z nového měření při použití škály odpovídá původním subškálám pomocí konfirmační faktorové analýzy). Obecně můžeme říci, že z metodologického hlediska je pak doporučováno při tvorbě indexů (summated rating scales) pracovat s indexy, které mají teoreticky konstruované subškály. $V$ případě, že celkový index nebude vykazovat vnitřní konzistenci, není možné s ním pracovat a faktorová analýza nám může pomoci najít funkční dílčí škály (pokud nějaké jsou). Spector (1992) navíc zdůrazňuje, že abychom mohli hovořit o několika dílčích indexech namísto jednoho souhrnného indexu, bylo by zapotřebí potvrdit souběžnou validitu těchto dílčích indexů, tedy na základě jejich vztahu k dalším konstruktům (výsledek faktorové analýzy není dle Spectora postačující pro používání dvou či více dílčích indexů namísto jednoho sumačního indexu celkové škály, která vykazuje vnitřní konzistenci). Při analýze dvou dílčích indexů (inkluze a exkluze) a jejich souvislostech $s$ dalšími proměnnými (především demografickými údaji) jsme však nenacházeli žádné výrazné odlišnosti, které by nám nějak usnadnily interpretaci a poskytly tak hlubší vhled do dat. I to nás vedlo k závěru pracovat $s$ jedním souhrnným indexem inkluze (a také rozsah článku, který by jinak výrazně narostl). $V$ takovém případě pak také pravidlo parsimonie říká, že je lepší zvolit jednodušší, tj. jednodimenzionální řešení (viz Spector 1992, s. 56). 
chozí části textu. Střed škály má hodnotu 2,5 (pro škálu 1 až 4), což znamená, že hodnotu průměru vyšší než zmíněná hodnota středu můžeme považovat za spiše inkluzívní a naopak hodnoty, které jsou nižší než 2,5 odpovídají postojům spiše exkluzivním, tedy podporujícím různé formy rozdělování žáků. Jak ukazuje popisná statistika indexu inkluze (viz tabulka č. 3), průměr je spíše na straně podpory exkluze (prům. index inkluze $=2,35$ ), ovšem vzdálenost od středu škály je poměrně malá. Postoje české veřejnosti i rodičů tak můžeme považovat za spíše podporující exkluzi, ale tato podpora není nijak výrazná a domníváme se, že jistá informační kampaň a osvěta může vnímání a postoje veřejnosti výrazně ovlivnit.

Tab. 4: Popisná statistika pro index inkluze (čím vyšší hodnota, tím vyšší podpora inkluzívního vzdělávání)

\begin{tabular}{|ll|c|c|}
\hline & & veřejnost & rodiče \\
\hline $\mathrm{N}$ & Valid & 1009 & 466 \\
& Missing & 17 & 8 \\
Průměr & & 2,35 & 2,32 \\
Směrodatná odchylka & 0,509 & 0,531 \\
Směr. chyba prüměru & 0,016 & 0,025 \\
Minimum & & 1,00 & 1,00 \\
Maximum & & 4,00 & 4,00 \\
Percentil & 25 & 2,00 & 2,00 \\
& 50 & 2,33 & 2,33 \\
& 75 & 2,67 & 2,67 \\
\hline
\end{tabular}

$V$ indexu inkluze jsou rovněž obsaženy odpovědi na obecnější otázky, kde veřejnost vyjadřovala podporu společnému vzdělávání různých žáků. Výzkum společnosti STEM/MARK realizovaný na vzorku 583 rodičů pak pokládal následující otázku: Je podle Vás správné, že $v$ našem školství se poměrně brzy dělí žáci rưzných schopností, že máme výběrové trídy, víceletá gymnázia a na druhé straně zvláštní školy, že rưzně nadané děti absolvují povinné vzdělávání odděleně? V této otázce jsou tak uvedeny hlavní institucionální podoby rozdělování žáků v českém vzdělávacím systému (tj. víceletá gymnázia, výběrové školy, zvláštní školy) a na tuto otázku pak rodiče vyjadřovali ve velké míre podporu současnému systému rozdělování žáků podle schopností ( $26 \%$ respondentů rozhodně souhlasilo a $50 \%$ respondentů s tvrzením spíše souhlasilo, průměr na čtyřbodové škále byl 2,0). Také odpověd' na tuto jednu dílčí, ovšem velmi obecně rozvedenou, otázku ukazuje, že společnost rozdělování žáků spiše podporuje. Nicméně již výše jsme uvedli výsledky téhož výzkumu, které potvrzují, že většina rodičů rovněž souhlasí s tím, že je možné rozvíjet nadání žáků i v běžné třídě, ve třídě složené ze žáků různých schopností. Výzkum společnosti STEM/MARK rovněž ukázal, že většina rodičů vnímá jako znepokojivý fakt, že vzdělanostní nerovnosti jsou v ČR vyšší než ve většině vyspělých zemích, že rozdíly ve vzdělání žáků vzdělaných rodičů a rodičů s nižším vzděláním 
patří k jedněm z největších (jak ukazují mezinárodní výzkumy, především výzkum PISA). Zároveň rodiče vyjádřili velkou podporu tvrzení, že škola má usilovat o odstraňování znevýhodnění dané rodinným zázemím žáků (výsledky výzkumu STEM/ MARK prezentujeme $v$ grafu č. 3). Odpovědi na tyto otázky tak podobně jako v našem výzkumu komplikují pohled na českou společnost jako ryze elitářskou a přinášejí další otázky, spíše než odpovědi.

Graf 3: Názory rodičů na nerovnosti ve vzdělávání a na rozdělování žáků (STEM/ MARK 2009)

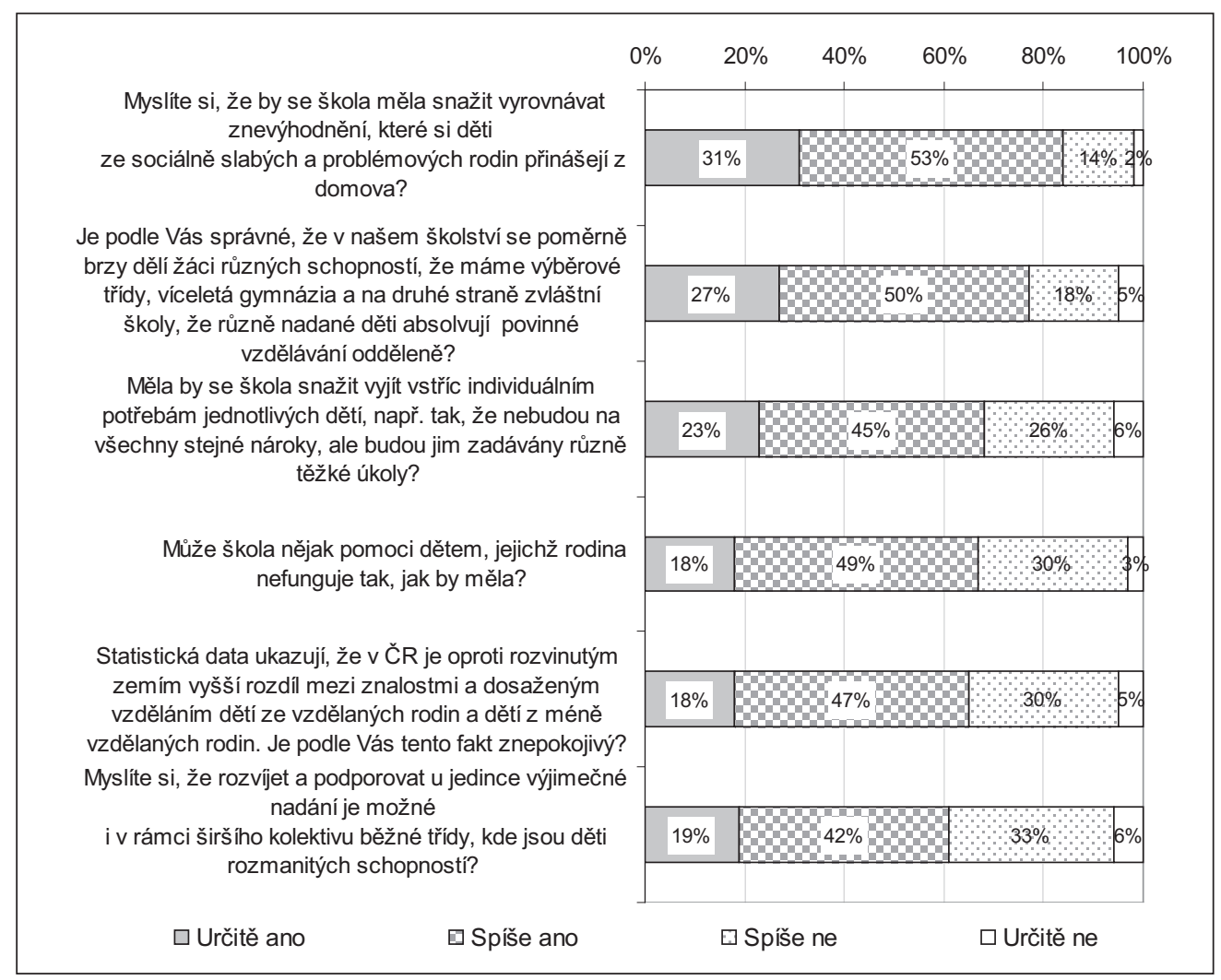

Zdroj: STEM/MARK, Sociologický výzkum pro MŠMT,

Akce RODINA - Rodiče o škole a vzdělávání, 4/2009, 583 respondentů

Přestože se neliší postoje $k$ inkluzi mezi rodiči (tedy těch, jejichž dítě realizuje povinnou školní docházku) a nerodiči, můžeme pozorovat velmi slabou souvislost (byt' statisticky významnou) mezi podporou inkluzi a věkem respondentů ( $r=$ $0,094, p=0,003)$. Nejmenší podporu společnému vzdělávání vyjadřují nejmladší respondenti (18-29 let, index inkluze $=2,24$ ) naopak nejvyšší hodnotu 2,41 dosáhl index inkluze u respondentů ve věku 40-49 let. Ještě pozitivněji ve prospěch inkluze se vyjadřovali nejstarší respondenti ve věku 60-69 let. Ti však odpovídali pouze na 4 otázky z celkové baterie výroků. Ve všech těchto otázkách však vykazovali 
nejvyšších hodnot podpory inkluzívnímu vzdělávání. Vezmeme-li i tuto skutečnost do úvahy, můžeme konstatovat, že s rostoucím věkem dotázaných sledujeme větší míru podpory inkluzi. Nicméně jak je dobře vidět i z tohoto srovnání, průměr všech věkových skupin je více nebo méně nalevo od středu škály, tedy napříč věkovými skupinami můžeme pozorovat spíše podporu rozdělování žáků. S rostoucím věkem se respondenti více přibližují k neutrálnímu středu škály 2,5 .

Statisticky významná souvislosti se dále ukázala mezi indexem inkluze a velikostí místa bydliště, nicméně i zde je asociace stejně slabá jako v prípadě věku respondentů (spearman $r=-0,092, p=0,003$ ). Koeficient korelace je záporný což znamená, že čím je obec menší, tím její obyvatelé vyjadřují větší podporu inkluzi. Naopak ve větších sídlech nabývá index inkluze nižších hodnot, což znamená, že ve velkých sídlech je podpora oddělenému vzdělávání žáků výraznější (pro sídla do 5.000 obyvatel je Index $i=2,44$, naopak nejnižší míra indexu inkluze $=2,27$ byla zjištěna u respondentů žijících v sídlech o velikosti 5000-20.000 obyvatel. Ve velkých městech nad 100.000 obyvatel nabýval index inkluze průměrných hodnot 2,33).

Index inkluze neprokázal žádnou souvislost s nejvyšším dosaženým vzděláním respondenta (korelační koeficient není statisticky významný). Nicméně analýzou rozptylu jsme potvrdili existenci rozdílů v podpoře inkluzívnímu vzdělávání mezi některými skupinami respondentů podle jejich vzdělání $(F=7,768, p=0,000)$. Nejvyšších hodnot dosahoval index inkluze u skupiny respondentů se středoškolským nematuritním vzděláním (Index $\mathrm{i}=2,44$ ), naopak nejnižší hodnotu měl u respondentů s dokončeným základním vzděláním (Index i = 2,24). Na první pohled to vypadalo, že respondenti s nejnižším vzděláním podporují nejvýrazněji rozdělování žáků do různých typů škol podle jejich schopností. Vysokoškoláci (index $i=2,28$ ) také podporují rozdělování žáků ve větší míre, než respondenti s maturitou (index $i=2,32$ ). Zjištění o výrazné podpoře rozdělování žáků (tedy nízké hodnotě indexu inkluze) u skupiny respondentů se základním vzděláním nás překvapil. Nicméně z části jej Ize vysvětlit i charakteristikou základního souboru, kterým byla populace dospělých v ČR, tedy respondenti ve věku od 18 do 69 let. V rámci respondentů, kteři uvedli jako nejvyšší dokončené vzdělání základní vzdělání je třetina $(33,3 \%)$ respondentů ve věku 18 a 19 let. Velká většina (ne-li všichni) těchto respondentů přitom budou studenti středních škol, kteří s největší pravděpodobností získají úplné středoškolské vzdělání a velká část z nich navíc bude dále studovat na vysoké škole. Tito respondenti se základním vzděláním ve věku 18 a 19 let tedy nejsou typickými představiteli veřejnosti se základním vzděláním, a jejich průměrná hodnota indexu inkluze (Index $\mathrm{i}=2,13$ ) proto také byla výrazně nižší od starších respondentů (starších než 20 let) jejichž průměrný index inkluze je $\mathrm{i}=2,39$. Po tomto „pročištění dat" a odfiltrování těch, kteří se jen v době šetření jeví jako zástupci veřejnosti se základním vzděláním, tedy při analýze pořadové korelace (Spearman) mezi indexem inkluze a nejvyšším dosaženým vzděláním pak již vychází korelace jako statisticky významná, přesto však velmi slabá, věcně nevýznamná ( $r=-0,092$, $p=-0,003)$.

Můžeme tedy shrnout, že rozdělování žáků podporují o něco více vysokoškolsky vzdělaní lidé. Právě lidé s nejvyšším kulturním a sociálním kapitálem se postavili ve- 
řejně na odpor návrhu ministra Eduarda Zemana z roku 2001 na rušení víceletých gymnázií. Jsou to právě vzdělaní rodiče, kteří nejvíce těží z časné diferenciace žáků. Dokáží připravit své děti na vstup do selektivních proudů (výběrových škol, víceletých gymnázií) a tím jim poskytnout konkurenční výhodu pro další výběr žáků na selektivní vysoké školy. Matějů a Straková (2003) ukázali s využitím dat z výzkumu PISA, že na víceletých gymnáziích studují žáci z rodin s vyšším sociálně-ekonomickým a kulturním kapitálem (70\% žáků víceletých gymnázií pochází z rodin, které se nacházejí ve dvou horních kvintilech sociálně-ekonomického a kulturního statusu, naopak děti z rodin umístěných v dolních dvou kvintilech SES tvoříjen 15\% žáků víceletých gymnázií). Stejně tak platí, že zatímco pouze $25 \%$ žáků základních škol má vysokoškolsky vzdělané rodiče, na víceletých gymnáziích má většina žáků rodiče s vysokoškolským diplomem ( $65 \%$ žáků). Vzhledem $\mathrm{k}$ tomu, že rodiče s vysokoškolským vzděláním zpravidla těží z existence časného rozdělování žáků podle schopností, je jejich nižší podpora inkluzívnímu vzdělávání v porovnání s dalšími vzdělanostními skupinami pochopitelná. Odfiltrováním studentů středních škol ze skupiny respondentů se základním vzděláním se podařilo vysvětlit na první pohled překvapivé zjištění o vysoké podpoře rozdělování žáků u těch, kteří z něj těží nejméně, tedy respondentů s nejnižším dosaženým vzděláním. Je zapotřebí ale zdůraznit, že přestože po odfiltrování respondentů ve věku 18 a 19 let, kteří uvedli jako nejvyšší dosažené vzdělání základní vzdělání, jsme nalezli statisticky významnou souvislost mezi vzděláním a indexem inkluze, síla tohoto vztahu je věcně zanedbatelná. Můžeme tedy očekávat, že stejně slabý vztah jako v našem výběrovém souboru existuje i v souboru základním, tedy v dospělé české populaci ve věku 18 až 69 let, nicméně síla tohoto vztahu je zanedbatelná a tedy nelze tvrdit, že by vzdělání silně podmiňovalo názory na rozdělování žáků.

S otázkou vzdělání respondentů (veřejnosti a rodičů) pak úzce souvisí také otázka na ideální vzdělávací dráhu pro jejich dítě (resp. vnuka nebo jiného příbuzného). Jedná se o otázku, která byla formulovaná následovně: Jak byste si v dnešní době představoval/a ideální průběh vzdělávání Vašich dětí po ukončení základní školy? (Pokud děti nemáte, nebo jsou již dospělé a podobně, pokuste se si tuto situaci představit). 1=bez dalšího vzdělání; $2=$ =odborné učiliště; 3=odborné učiliště ukončené maturitou; $4=$ střední odborná škola; $5=$ gymnázium. Souvislost mezi odpovědí na tuto otázku a indexem inkluze byla jedna z nejsilnějších $(r=-0,201, p=0,000)$. Tedy čím náročnější typ studia po základní škole rodiče volili, tím nižší byla jejich podpora inkluzívnímu vzdělávání. Největší podporu inkluzi tak vyjadřují rodiče, kteři pro své děti považují za nejlepší vzdělání po základní škole učební obor bez maturity (index $i=2,49$, a není statisticky odlišný od středu škály 2,5). Naopak největší podporu rozdělování vyjadřovali ti respondenti, kteři pro své dítě považují za nejlepší, aby po základní škole pokračoval/a na gymnáziu (index $i=2,16$ ) a dále ti, kteří by volili střední odbornou školu s maturitou (index $i=2,37$ ).

Stejně tak se ukázala souvislost mezi obecnými postoji k přijímání žáků na střední školy a mírou podpory inkluzi. Předně ti, kteří přiznávají, že „to, na jakou střední školu se dítě dostane, výrazně ovlivní jeho budoucí život" zároveň mají nižší hodnoty indexu inkluze a podporují tak spiše rozdělování žáků $(r=0,217, p=0,000)$; 
stejně tak lidé s nižším indexem inkluze častěji vyjadřují přesvědčení, že „o přijetí na střední školu rozhodují především schopnosti žáka“ $(r=0,145, p=0,000)$ a naopak se nedomnívají, že by prijímací rízení provázela protekce $(r=-0,139, p=0,000)$. Toto zjištění není nikterak překvapivé, naopak potvrzuje spíše logiku a konzistentnost indexu. Bylo by překvapivé, kdyby ti, kteří podporují rozdělování žáků podle schopností nevěřili ve schopnost systému toto rozdělení efektivně provést a kdyby tedy přijímací rízení zpochybňovali. To je naopak typické u odpůrců rozdělování žáků na základě schopností (vnější diferenciace), kteří ukazují na nedostatečnou kapacitu prijij́macího řízení odhalit schopnosti žáka, navíc zdůrazňují, že čím dříve dochází $\mathrm{k}$ selekci, tím větší roli hraje $v$ úspěchu tranzice rodinné zázemí žáka a tím dochází ke zvyšování vzdělanostních nerovností a podmíněnosti vzdělání sociálně-ekonomickým statusem rodiny.

Rovněž můžeme dodat, že ta část veřejnosti, která dosahuje vyšších hodnot indexu inkluze a jejiž podpora rozdělování dětí je nejslabší, si zároveň více cení výchovné funkce školy. Na otázku „Kdo je podle vás zodpovědný za výchovu dětí" (devítibodová škála s krajními pozicemi: pouze rodiče - stejná odpovědnost školy i rodičů - pouze škola) tak lidé $s$ vyšším indexem inkluze přiznávali škole ve větší míre také výchovnou funkci $(r=0,156, p=0,000)$. Stejně tak lidé s vyšší hodnotou indexu inkluze častěji přisuzovali vzdělání hodnotu veřejného statku $(r=0,124$, $\mathrm{p}=0,000$ ). Respondenti měli vybrat jeden z následujících výroků, podle toho, se kterým více souhlasí: 1) Dosáhnout určitého vzdělání je $v$ zájmu člověka samého, protože je to koneckonců on sám, kdo z toho bude mít největší užitek. 2) Umožnit co nejlepší vzdělání co největšímu počtu obyvatel by měl stát, protože je to $v$ zájmu celé společnosti. $V$ datovém souboru rodičů $(N=474)$ byl průměrný index i pro respondenty, kteří chápou vzdělání spíše jako soukromý statek (private consumer good) 2,294 a pro respondenty, u kterých převažuje vnímání vzdělání jako prínosu pro společnost (public good) je průměrná hodnota indexu $i=2,421$. Dvouvýběrový $\mathrm{t}$-test potvrdil statisticky významné rozdíly $\mathrm{v}$ průmèrech obou skupin ( $\mathrm{t}=$ $-3,922, \mathrm{p}=0,000$ ).

Výše uvedené vztahy nám ukázaly, jak postoje k inkluzi vyjádřené indexem inkluze souvisejí s dalšími (nejen socio-demografickými) proměnnými z našeho výzkumu. Stejně tak jsme nalezli rozdíly ve vnímání inkluze v různých krajích ČR (analýzou rozptylu, $F=8,356, d f=13, p=0,000$ ). Nejnižší průměrnou hodnotu indexu inkluze vykazoval kraj Pardubický (index $i=1,86$ ), naopak největší podporu inkluzívnímu vzdělávání můžeme pozorovat v kraji Olomouckém (index $i=2,59$ ), Vysočina (index $i=2,58$ ) a $\vee$ kraji Zlínském (index $i=2,51$ ). Pouze $v$ těchto třech krajích se průměrná hodnota indexu pohybovala napravo od středu škály 2,5 , lidé vyjadřovali spiše podporu inkluzívnímu vzdělávání. Náš předpoklad, že největší podporu bude mít rozdělování žáků ve velkých městech a především v Praze a tak že v Praze bude nejnižší hodnota indexu inkluze, se nepotvrdil. Přestože ve velkých městech je největší množství víceletých gymnázií a výběrových škol, v názorech respondentů se to nezrcadlilo. Pro rozdíly mezi jednotlivými kraji navíc nemáme žádné další teoretické vysvětlení.

Zajímalo nás taky, jak se hodnota indexu inkluze liší podle politických preferencí 
jednotlivých stran. Přestože na první pohled nejvyšší průměrný index inkluze vykazovali stoupenci KDU-ČSL ${ }^{14}$ (index $i=2,52$ ), a naopak nejnižší hodnotu indexu stoupenci ODS (index $i=2,31$ ), což v obou případech odpovídalo našim očekáváním, rozdíly $v$ průměrných hodnotách indexu pro stoupence jednotlivých politických stran se neukázaly být statisticky významné (hypotézu o rozdílnosti průměru jsme ověřovali pomocí jednorozměrné analýzy rozptylu i s využitím neparametrického Kruskal-Wallisova testu). Nemůžeme tedy spolehlivě ríci, že rozdíly $v$ průměrných hodnotách, které jsme zjistily v našem souboru, bychom našli i v cílové populaci mezi příznivci politických stran. Můžeme tedy uzavřít, že otázky rozdělování žáků v rámci povinného vzdělávání nepatří k tématům, která by rozdělovala či profilovala voliče jednotlivých stran. To je zajímavé zjištění už z toho důvodu, že v otázkách především víceletých gymnázií, ale také podpoře dalšímu rozdělování (výběrových základních škol apod.) se v roce 2001 některé strany takto profilovaly (ODS především na podporu zachování rozdělování žáků, ČSSD naopak přišla s návrhem jejich rušení). Je možné, že se jednalo jen o ideologický střet hlavní vládní strany a opozice, nicméně naše data nepodporují představu, že by se tím nějak výrazně svým příznivcům kterákoli ze stran zalíbila. V obou táborech jsou jak příznivci, tak odpůrci rozdělování žáků a jejich poměr není v prospěch žádné z těchto skupin pro obě strany (vycházíme $z$ analýzy nejen indexu, ale také z analýzy odpovědí na jednotlivé otázky, které do indexu vstupují).

\section{DISKUSE}

Analýza postojů k rozdělování žáků ukázala, že se jedná o téma, na které česká veřejnost a rodiče nemají př́liš ujasněný názor. $Z$ analýzy konzistence odpovědi respondentů na protichůdné výroky vyplynulo, že velká část respondentů odpovídá do jisté míry nekonzistentně. Mưže tomu tak být hned z několika důvodů. Jednak to může být způsobeno obecným stavem české společnosti, kde se mísí touha po rovnosti s touhou po individualismu. Dále to může být dáno také tím, že otázky vzdělávání, jejich hlubší souvislosti a cíle vzdělávání nejsou veřejně diskutovány (at' již představiteli státu, včetně ministerstva školství, tak výzkumníky, kteří málo veřejně vystupují) a lidé tak mají tendenci odpovídat na jednotlivé otázky s přihlédnutím k osobním zkušenostem, které se mohou z teoretického hlediska jevit nekonzistentně. Respondenti tak zřejmě odpovídají na jednotlivé otázky především na základě vlastní zkušenosti, tam kde ji nemají pak mohou odpovídat obecněji, na základě obecného přesvědčení. Respondenti, kteří učinili zkušenost s víceletým gymnáziem (at' již oni, či jejich dítě nebo jiná blízká osoba ve výsledku byla nebo nebyla na víceleté gymnázium príjata) mohou na otázky ve vztahu k víceletým gymnáziím odpovídat na základě této (pozitivní či negativní skutečnosti) a na otázky další (např. o žácích s poruchami učení) pak odpovídat obecněji bez jakékoliv zkušenosti. Tendence respondentů na otázky vzdělávání odpovídat osob-

14 Jak jsme ukázali výše, nejvyšší podporu inkluzi vyjadřují obyvatelé Zlínského a Olomouckého kraje s krajem Vysočina. Především první dva kraje jsou tradičně místem, kde má KDU-ČSL velkou část svých skalních příznivců. 
ními zkušenostmi a příklady jedinců bez přihlédnutí k celku či obecným principů je zřejmá z veřejných diskusí, vystoupení v médiích nebo nejlépe při prohlédnutí internetových diskusí ke článkům a blogům věnovaným právě otázce vzdělávání. V otázkách spravedlivosti (nejen) vzdělávání navíc u těch respondentů, kteří neodpovídají pouze na základě dílčích zkušeností jedinců, ale mají zformovaný nějaký obecnější názor, může být tento názor v rozporu $s$ jejich jednáním v prípadě jejich konkrétního dítěte, v zájmu svých dětí. Tento střet hodnot popsal dobře $v$ anglickém prostředí Adam Swift (2003) v knize Jak nebýt pokrytcem: Volba školy pro morálně zmatené rodiče. $V$ českém vzdělávání $k$ jistému střetu hodnot (obecného principu a skutečného jednání) dochází u rodičủ, kteří obecně připouštějí nevýhody rozdělování a přiznávají výhody společného vzdělávání různých dětí, ale přesto své dítě prihlásí na víceleté gymnáziu, protože je to pro jeho budoucnost nejlepší. Není zřejmé, jak tito rodiče odpovídali na baterii námi nabídnutých výroků, kde by prevážil obecný princip a kde by naopak vycházeli z konkrétní zkušenosti a reflexe svých vlastních rozhodnutí. Při analýze názorů rodičů a veřejnosti k rozdělování žáků je zapotřebí mít tuto škálu možných vlivů, které se skrývají za jejich odpověd'mi, na paměti. Rozsáhlejším dotazníkovým šetřením, které by sledovalo jen postoje veřejnosti k časné diferenciaci a mapovalo by jejich zkušenosti se vzdělávacím systémem, by bylo možné pokročit o něco dále v porozumění tomu, jaké názory česká veřejnost má a jak se utvářejí. Další pohled do struktury postojů by mohl vnést kvalitativní výzkum. Z našich dat celkového veřejného mínění však není možné blíže tyto vlivy postihnout. Také $v$ našem souboru rodičů $(N=474)$ je několik respondentů, jejichž děti studují na víceletých gymnáziích (26 respondentů). Výpovědi těchto respondentů jsou výrazněji na podporu rozdělování žáků ve všech otázkách na časné rozdělování žáků, které pochopitelně podporují ve větší míře než ostatní rodiče. (vyjádřeno souhrnně indexem inkluze $i=2,06$, naproti tomu ostatní rodiče $i=2,34)$. Nicméně malý soubor těchto rodičů nám neumožňuje sílu rozdílů ve vnímání inkluze mezi rodiči, jejichž dětí studují ve výběrových školách a těmi, kteří nikoliv, zobecňovat. Poukazuje však na skutečnost, která je pochopitelná a nepřekvapivá a může taky podpořit skutečnost, že rodiče (ale i širší veřejnost) na otázky školství odpovídají především prizmatem osobních zkušeností, zkušeností svých dětí a vnuků, spíše než na základě obecného uvažování nebo reflexe diskusí, které se tématům školství príliš nevěnují.

Kromě komplexnosti názorů na časnou diferenciaci (či obráceně inkluzi) rodičů a veřejnosti je však možno hovořit o tom, že jednotlivé otázky, které jsme respondentům pokládali, vypovídali o vnímání obecnějšího konstruktu, který jsme sledovali při konstruování indexu inkluze. Smyslem tvorby sumačních indexů je zachytit postoje či názory, které jsou prímo neměřitelné. Tím jsme, dle našeho názoru, postoupili o něco dále $v$ hledání odpovědi na to, nakolik je česká veřejnost inkluzívní. $\checkmark$ předchozích výzkumech bylo vždy použito jen několika dílčích otázek. Nicméně zjištění oběma př́stupy (viz $v$ textu prezentované analýzy jednotlivých otázek i souhrnného indexu inkluze $z$ našeho výzkumu a zjištění jiných výzkumů - např. výzkum STEM/MARK 2008, jehož některé výsledky v textu prezentujeme) ukazuje, že česká veřejnost i rodičovská veřejnost vyslovuje spíše podporu rozdělování žáků 
podle jejich schopností, studijních předpokladů nebo na základě jejich studijních výsledků. Překvapivá však byla zároveň poměrně velká podpora výrokům podporujícím společné vzdělávání odlišných žáků. $Z$ bližšího pohledu na postoje veřejnosti pomocí zkonstruovaného indexu inkluze se ukázalo, že přestože převažuje spíše podpora rozdělování žáků, tato podpora není nijak výrazná - nachází se jen nepatrně od neutrálního středu na škále exkluze (rozdělování žáků) a inkluze (společné vzdělávání odlišných žáků).

Postoje $\mathrm{k}$ rozdělování žáků navíc nejsou výrazně podmíněny socio-demografickými charakteristikami (byt' se ukázaly statisticky významné rozdíly ve vnímání různých skupin obyvatel - podle velikosti sídla, věku, vzdělání - věcně tyto rozdíly významné nejsou a síla vztahů je zanedbatelná). V různých řezech společností tak odlišné skupiny nevykazují nějakou zásadní odlišnost v názorech na tyto otázky. Z tohoto pohledu pak zvláště zajímavé je, že jsme neshledali žádné rozdíly ve vnímání této otázek o rozdělování žáků (obecněji postojích k inkluzívnímu vzdělávání) u voličů různých politických stran. Problematika rozdělování žáků by tak nemusela být politizována a názory těch, kteři ranou diferenciaci žáků odporují by nemusely být interpretovány jako levicové, jak tomu v minulosti bývalo. Ukázalo se totiž nejen to, že mezi voliči všech stran jsou jak zastánci tak odpưrci časného rozdělování žáků, ale taky že pravolevá škála voličských preferencí zde také nijak nediferencuje. Politizace těchto témat, jak jsme ji mohli vidět například při snaze zrušit víceletá gymnázia v roce 2001, tak nemá opodstatnění ve vyhraněnosti voličské základny politických stran, jak by se mohlo zdát.

Důležité je, že některé argumenty, které Ize použít pro vysvětlování nevýhod rozdělování žáků mají výraznou podporu veřejnosti. Například se ukazuje, že veřejnost velmi znepokojují rostoucí vzdělanostní nerovnosti v ČR. Nicméně jim chybí propojení se zjištěním výzkumů, že jednou z důležitých příčin růstu vzdělanostních nerovností u nás je právě rané rozdělování žáků do víceletých gymnázií či výběrových škol. Zde se otevírá prostor pro vysvětlování výsledků výzkumů veřejnosti, a to jak pedagogickými výzkumníky (kteři zde mají vůči společnosti jistý dluh), tak i osvícenými politiky, kteří by byli schopni výsledky těchto výzkumů účinně komunikovat směrem k veřejnosti.

V současné době ti, jejichž postoje jsou více inkluzívní (tj. podporují společné vzdělávání rozličných žáků a naopak jsou kritičtí k rozdělování žáků), kladou dưraz na výchovnou funkci školy. Dosud se však zdá, že zjištění pedagogických výzkumů, které navíc ukazují, že rozdělování žáků je neefektivní, neb snižuje průměrný výsledek vzdělávání žáků, není běžně známo ani príijímáno. Právě tato skutečnost odporuje hlavnímu argumentu obhájců časného rozdělování - vždyt’ to všem prospěje! $\checkmark$ neposlední řadě pak lidé, jejichž postoje jsou více inkluzívní taky vyjadřují pochybnosti směrem k prijímacímu řizení a samotnému výběru žákủ. I zde jsou jejich názory blízké zjištěním pedagogického výzkumu, které ukazují, že neumíme vybrat ty nejlepší, neb nejenže je obtížné měřit skutečné schopnosti či studijní předpokla$d y$, ale především pak proto, že v raném věku má na výsledek přijetí mnohem větší vliv rodinné zázemí dítěte, než jeho skutečné schopnosti.

Na základě analýzy dat se domníváme, že s postoji veřejnosti k rozdělování žáků 
Ize dále pracovat. Navíc se postoje veřejnosti nejeví tak vyhraněně pro rozdělování žáků, jak se mohlo zdát z mediálních reakcí na návrh zrušit víceletá gymnázia v roce 2001. Ukazuje se tak jako důležité pokračovat v domácích výzkumech zjištujících dopady rozdělování žáků $v$ českém prostředí, kde nám chybí především longitudinální výzkumy, které by umožnily změřit přidanou hodnotu výběrových a nevýběrových škol. Nicméně jako stejně důležitá se ukazuje potřeba komunikovat výsledky těchto výzkumů směrem $k$ veřejnosti a otevř́t veřejnou diskusi o podobě a funkcích vzdělávání v České republice.

\section{LITERATURA}

Clark, L.A.; Watson, D. Constructing Validity: Basic Issues in Objective Scale Development. Psychological Assessment, 1995, roč. 7, č. 3, s. 309-319.

Černý, K.; Walterová, E. Vzdělávací potřeby pro 21. století. Orbis Scholae, 2006, roč. 1, č. 1, s. 60-77.

DeVellis, R.F. Scale Development: Theory and Applications. 2nd Ed. Tousand Oaks, CA:Sage, 2003.

Gamoran, A.; Berends, M. The effects of stratification in secondary schools: Synthesis of surveys and ethnographic research. Review of Educational Research, 1987, roč. 57, č. 4, s. 415-435.

Gamoran, A.; Mare, R.D. Secondary school tracking and educational inequality: Compensation, Reinforcement or neutrality? American Journal of Sociology, 1989 , roč. 94, č. 5, s. 1146-1183.

Greger, D. Koncept spravedlivosti a diferenciace žáků. In WALTEROVÁ, E. a kol. Úloha školy v rozvoji vzdělanosti. 2. díl. Brno: PAIDO, 2004, s. 362-370.

Greger, D. Vzdělanostní nerovnosti v teoretické reflexi. In Matějů, P.; Straková, J. (eds.) Nerovné šance na vzdělání: Vzdělanostní nerovnosti v České republice. Praha: Academia, 2006, s. 21-40.

Greger, D. The development and debating of the comprehensive school model in the Czech Republic and other Central and Eastern European Countries (CEECs). Paris: AECSE, 2005. dostupné na WWW: <http://ep.inrp.fr/EP/colloques/colloque_construction_deconstruction/the-development-and-debating-of-the-comprehensive-school-model-in-the-czech-republic-and-other-central-and-eastern-european-countries-ceec?set_language=en>.vstup 10.6. 2009

Greger, D. Lorsque PISA importe peu. Le cas de la République tchèque et de l'Allemagne. Revue française de pédagogie, 2008, n 164, s. 91-98.

Kerckhoff, A.C. Effects of ability grouping in British secondary schools. American Sociological Review, 1986, roč. 51, č. 6, s. 842-858.

Lannert, J.; Mártonfi, G.; Vágó, I. Understanding social demand for schooling in Hungary. Paris: OECD, 2004.

Matějů, P.; Straková, J. Role rodiny a školy v reprodukci vzdělanostních nerovností. Sociologický časopis, 2003, roč. 39 , č. 5, s. 625-652.

Oakes, J. Keeping track: How schools structure inequality. New Heaven, CT: Yale University Press, 1985. 
OECD. Knowledge and skills for life: First Results from PISA 2000. Paris: OECD, 2001.

Rosenbaum, J. Making inequality: The hidden curriculum of high school tracking. New York: Willey, 1976.

Slavin, R.E. Ability grouping in secondary schools: A response to Hallinan. Review of Educational Research, 1990a, roč. 90, s. 505-507.

Slavin, R.E. Achievement effects of ability-grouping in secondary schools: A bestevidence synthesis. Review of Educational Research, 1990, roč. 60, č. 3, s. 471-499.

Spector, P.E. Summated Rating Scale Construction: An Introduction. Newbury Park, CA: Sage, 1992.

Swift, A. How not to be a hypocrite. School choice for the morally perplexed parent. London: Routledge, 2003. 